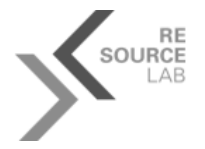

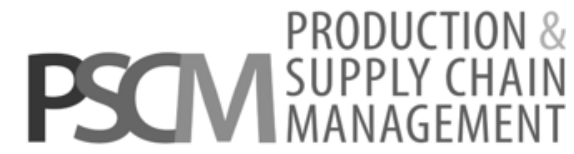

Postprint

\title{
Supply risks associated with lithium-ion battery materials
}

\author{
Christoph Helbig ${ }^{*}$,, Alex M. Bradshaw ${ }^{\mathrm{b}, \mathrm{c}}$, Lars Wietschel ${ }^{\mathrm{a}}$, Andrea Thorenz ${ }^{\mathrm{a}}$, Axel Tuma ${ }^{\mathrm{a}}$ \\ *Address correspondence to: christoph.helbig@wiwi.uni-augsburg.de \\ ${ }^{a}$ : Resource Lab, Institute of Materials Resource Management, University of Augsburg, \\ Universitaetsstr. 16, 86159 Augsburg, Germany \\ b: Max Planck Institute for Plasma Physics, Boltzmannstraße 2, 85748 Garching, Germany \\ c: Fritz Haber Institute, Faradayweg 4-6, 14195 Berlin, Germany
}

Published in: Journal of Cleaner Production 172 (2018) 274-286/

https://doi.org/10.1016/j.jclepro.2017.10.122

\begin{abstract}
One possibility for electrification of road transport consists of battery electric vehicles in combination with carbon-free sources of electricity. It is highly likely that lithium-ion batteries will provide the basis for this development. In the present paper, we use a recently developed, semi-quantitative assessment scheme to evaluate the relative supply risks associated with the elements used in the functional materials of six different lithium-ion battery types. Eleven different indicators in four supply risk categories are applied to each element; the weighting of the indicators is determined by external experts within the framework of an Analytic Hierarchy Process. The range of supply risk values on the elemental level is distinctly narrower than in our previous work on photovoltaic materials. The highest values are obtained for lithium and cobalt; the lowest for aluminium and titanium. Copper, iron, nickel, carbon (graphite), manganese and phosphorous form the middle group. We then carry out the assessment of the six battery types, to give comparative supply risks at the technology level. For this purpose the elemental supply risk values are aggregated using four different methods. Due to the small spread at the elemental level the supply risk values in all four aggregation methods also lie in a narrow range. Removing lithium, aluminium and phosphorous from the analysis, which are present in all types of battery, improves the situation. For aggregation with the simple arithmetic mean, an uncertainty analysis shows that only lithium-iron phosphate has a measurably lower supply risk compared to the other battery types. For the "cost-share" aggregation using seven elements, lithium cobalt oxide has a substantially higher supply risk than most other types.
\end{abstract}

\section{Keywords}

supply risk; batteries; lithium-ion; analytic hierarchy process; monte carlo simulation 


\section{Introduction}

On account of its high specific energy, relatively low cost and long cycle life, the lithium-ion battery in its various forms has found many applications in the last two decades (Eisler, 2016; Goodenough and Park, 2013; Tarascon and Armand, 2001; Yoshino, 2012). These range from consumer electronics, computer notebooks, mobile phones and power tools to electric vehicles and even stationary grid storage. As has been recently pointed out (Blomgren, 2017; Hu et al., 2017; Kim et al., 2012), installed capacity is expected to grow rapidly in future due to performance improvements and sinking costs. Electric vehicles and grid storage are likely to be particularly strong growth areas(Hu et al., 2017). The reason is to be found in the efforts currently being made internationally to limit greenhouse gas (GHG) emissions. The main goal of the climate agreement concluded in 2015 in Paris (COP21) is to hold global warming to "well below $2^{\circ} \mathrm{C}$ above pre-industrial levels" and, moreover, "to pursue efforts to limit the increase to $1.5^{\circ} \mathrm{C}^{\prime \prime}$ (United Nations/Framework Convention on Climate Change, 2015). This can only be achieved if sometime in the second half of this century net GHG emissions are reduced to zero globally. Since road transport alone is currently responsible for about $20 \%$ of GHG emissions in, for example, the EU (Eurostat, 2016a), one obvious route is the electrification of this sector in combination with low carbon, or carbon-free, sources of electrical energy. In the second area mentioned, namely, stationary grid storage, Li-ion battery technology may be used increasingly to combat mainly short-term intermittency problems associated with renewable energy sources (Arbabzadeh et al., 2016). The present paper is largely motivated by the current discussion on the possible, foreseeable material requirements for electrification in the transport sector and grid storage as well as on the concomitant supply risks associated with these metals and minerals. The supply risks require early identification and may also need international action for their mitigation (Ali et al., 2017). Using a recently developed procedure the paper compares in a semiquantitative way the supply risks associated not only with the key metals and minerals, but also with the technologies used in Li-ion batteries.

The solution for the transport sector that has received the most attention is the battery electric vehicle (BEV). Other battery solutions, such as the hybrid or plug-in hybrid electric vehicle, are unlikely to satisfy the strict emission requirements likely to become obligatory in the course of the next few decades (e.g. Hu et al., 2016; Marina Martinez et al., 2016). (So-called extended range electric vehicles might satisfy the requirements, if the supplementary liquid fuel derives from renewable sources.) If a complete switch to BEVs were to occur in the next two or three decades, then it is likely, at least for cars and vans, that they would also be powered by lithium-ion batteries. In the longer term, it is possible that other battery types, such as lithium-sulphur or lithium-oxygen, will by then have more favourable characteristics, such as higher specific energy and/or lower costs. The other alternative for the power train in an electric vehicle is the hydrogen-powered PEM fuel cell, where PEM stands for "proton exchange membrane" (Gröger et al., 2015). In this case there are also material problems: not only the fuel cell itself, but also the electrolyser for producing the hydrogen fuel from water, is likely to require electrodes composed of platinum group metals. There are considerable supply risks associated with these materials; their costs are also considered rather high, at least in comparison with lithium and the transition metals used in Li-ion batteries. On the other hand, fuel cell electric vehicles (FCEVs) in the category "mid-size family car" already have, unlike BEVs, a driving range of $~ 500 \mathrm{~km}$ using hydrogen stored in high pressure tanks. Which of the two power train systems will ultimately prevail, may depend on public acceptance. The reader is referred to the review article by Gröger et al. (Gröger et al., 2015) for a fuller discussion. A glance at a recent document of the European Commission shows that detailed plans are being laid, and 
incentives planned, in order to promote the introduction in Europe of low and zero emission vehicles on the timescale indicated above (European Commission, 2016).

The recent increase in the contribution of renewable energy to electrical supply, at least in Europe (2014: $27.5 \%$ of gross electricity consumption (Eurostat, 2016b)), derives mainly from the installation of photovoltaic modules and wind turbines. These intermittent sources give rise, however, to an increased demand for electricity storage capability that will inevitably increase in coming years. This will occur at various levels. Firstly, there is the need for balancing, or "smoothing" stochastic fluctuations on the scale of seconds and minutes which come about not only because of intermittency in supply but also because of consumer behaviour. Secondly, fluctuations occur inevitably on the timescale of a day, or of a few days, for example, the differences between night and day, but also as a result of extended periods of weather not conducive to electricity generation. Combatting fluctuations of this sort is sometimes referred to as "load levelling" or "peak shaving". Thirdly, there are fluctuations on a seasonal level, i.e. on the scale of months, in particular differences between summer and winter. Because of the huge amounts of energy that would be required for coping with seasonal variations, it is generally agreed that pumped hydroelectric storage (PHS) is probably the only viable solution. At present, battery-based solutions in connection with the first two categories represent less than $1 \%$ of the total installed storage capacity in Europe (Geth et al., 2015). At the time of writing, it is not possible to estimate the likelihood of battery-based storage playing a major role in the grid of the future.

Nevertheless, from our present vantage point, it is clear that the decarbonisation of transport can only occur through the large-scale introduction of BEVs or FCEVs. Whereas it is unlikely that both technology approaches will be applied in parallel because of the high infrastructure costs, the chances that the BEV will make the running are good. The advantages of Li-ion battery technologies over other rechargeable batteries are consistent in technical, environmental and cost assessments (Hammond and Hazeldine, 2015). Since a rough estimate would put the number of cars and vans in the global road vehicle fleet at approximately $10^{9}$ (we exclude trucks, as well as other transport forms, in particular shipping and air traffic, for which other solutions will probably have to be found), the question of the raw materials required for lithium-ion batteries and the concomitant supply risks needs to be addressed. The rapid market growth and a lack of closed-loop recycling of Li-ion batteries make it unlikely that secondary material sources will be available in the near future (Zeng et al., 2014). Because of the different chemistries in different types of battery, we also consider here, apart from lithium itself (Li availability is also discussed in other scientific papers, e.g. (Vikström et al., 2013), as well as in magazine articles, e.g. (The Economist, 2017)), the supply risks associated with the several other elements used as functional materials.

The supply risks for raw materials, in particular for rare metals ${ }^{1}$, are influenced by such factors as the possible dwindling of resources, increases in demand for the element in other industrial applications or the occurrence of monopolies and cartels. Physical shortage and longer delivery times as well as price rises and geopolitical tension could have substantial negative implications for battery or car producers and complicate the large-scale introduction of BEVs. The increased attention paid to such questions of raw material supply dates back to a study of the National Research Council (NRC) of the US National Academies in 2008 with the title "Minerals, critical minerals, and the US economy" (U.S.

\footnotetext{
${ }^{1}$ An element is normally considered "rare" if its concentration in the Earth's crust is below about $0.1 \%$. In a recent, more popular, but percipient work on minerals and commodity markets Abraham (Abraham, 2015) also seems to prefer "rare metals" to "critical metals", a term for which there is no agreed definition (Bradshaw et al., 2013).
} 
National Research Council, 2008). Many investigations have since followed, several of them concerned specifically with energy-related materials (Goe and Gaustad, 2014; Moss et al., 2013, 2011; Roelich et al., 2014; U.S. Department of Energy, 2011; Zepf et al., 2014). The US Department of Energy (U.S. Department of Energy, 2011) assessed the supply risks associated with various materials required for different technologies in the clean energy sector such as photovoltaics, wind turbines and electric vehicles. Similarly, Moss et al. (Moss et al., 2013) identified resource requirements for various green energy technologies necessary for the implementation of the EU decarbonisation strategy and evaluated supply risk. Subsequent studies, such as that of Goe and Gaustad (Goe and Gaustad, 2014) focussed on the US, looked at the raw materials necessary for specific green energy technologies, but without comparing specifically the different technical solutions (e.g. in thin-film photovoltaics).

As described in two earlier papers (Helbig et al., 2016; Tuma et al., 2014), our philosophy is somewhat different from that in most previous resource studies. We think it is only meaningful to assess supply risks semi-quantitatively (i.e. the likelihood of supply being unable to meet demand), if it is done on a comparative basis. In the present paper, we therefore first determine the supply risks associated with the elements required for the functional materials. Eleven indicators covering the main areas of supply risk are used, as in our previous work on thin-film photovoltaics (Helbig et al., 2016); these are categorized and weighted for the specific case of lithium-ion batteries. The relative supply risks determined in this way for the elements concerned are then combined to produce relative supply risks for the different battery types. For this purpose various aggregation procedures are investigated, the simplest of which just involves taking the arithmetic mean. The structure of the article is as follows: In the next chapter the lithium-ion battery is described briefly on a general level, and information is given on some of the more common battery types. The list of elements in the present study is discussed and previous work on supply risk, in particular in connection with resource depletion, described. The specific method we use for assessing supply risks on the elemental and technology levels is described in chapter 3 . We then present results in chapter 4 for the semiquantitative supply risk assessment for the elements themselves and for the selected list of Li-ion battery technologies. The article ends with a discussion of the results and some conclusions.

\section{Battery composition and previous supply risk studies}

A schematic illustration of a rechargeable Li-ion battery cell - actually of the original $\mathrm{LiCoO}_{2} / \mathrm{graphite}$ (LCO-C) cell - is shown in Fig. 1 (Peters and Weil, 2016). A battery may consist of one or several such cells that are connected in series or in parallel. Each cell consists of two electrodes (anode and cathode), both containing active material, binder and current collector as well as a $\mathrm{Li}^{+}$-conducting electrolyte consisting of $\mathrm{LiPF}_{6}$ in organic solution. A porous polymer separator is used to prevent electrical and mechanical contact between the electrodes. Because of the high reactivity of lithium the whole system must be kept strictly free of water. A battery management system monitoring and controlling individual cell voltages, battery temperature and possible overloading increases safety and lifetime of the battery (Jaguemont et al., 2016). The battery is based on the principle of reversible, alternate intercalation of $\mathrm{Li}$ ions in graphite at the anode and in a lithium compound (e.g. a cobaltate) at the cathode. Thus, on discharging the battery, lithium atoms in or on the anode ionize into the electrolyte as $\mathrm{Li}^{+}$, from where they migrate to the cathode. Here, a transition metal oxide is reduced by acquiring electrons from the external circuit, so that the $\mathrm{Li}$ ions can be incorporated into the lattice. At the same time, electrons move from the anode through the external circuit to the cathode. The reverse process occurs on charging. Figure 1 is drawn to demonstrate specifically the 
discharge process. The usual battery parameters, namely, energy density, power density, specific energy, capacity, charging time and lifetime, as used in this article, are defined in Ref. (Nitta et al., 2015; Sterner and Stadler, 2014; Yu and Zhou, 2013).

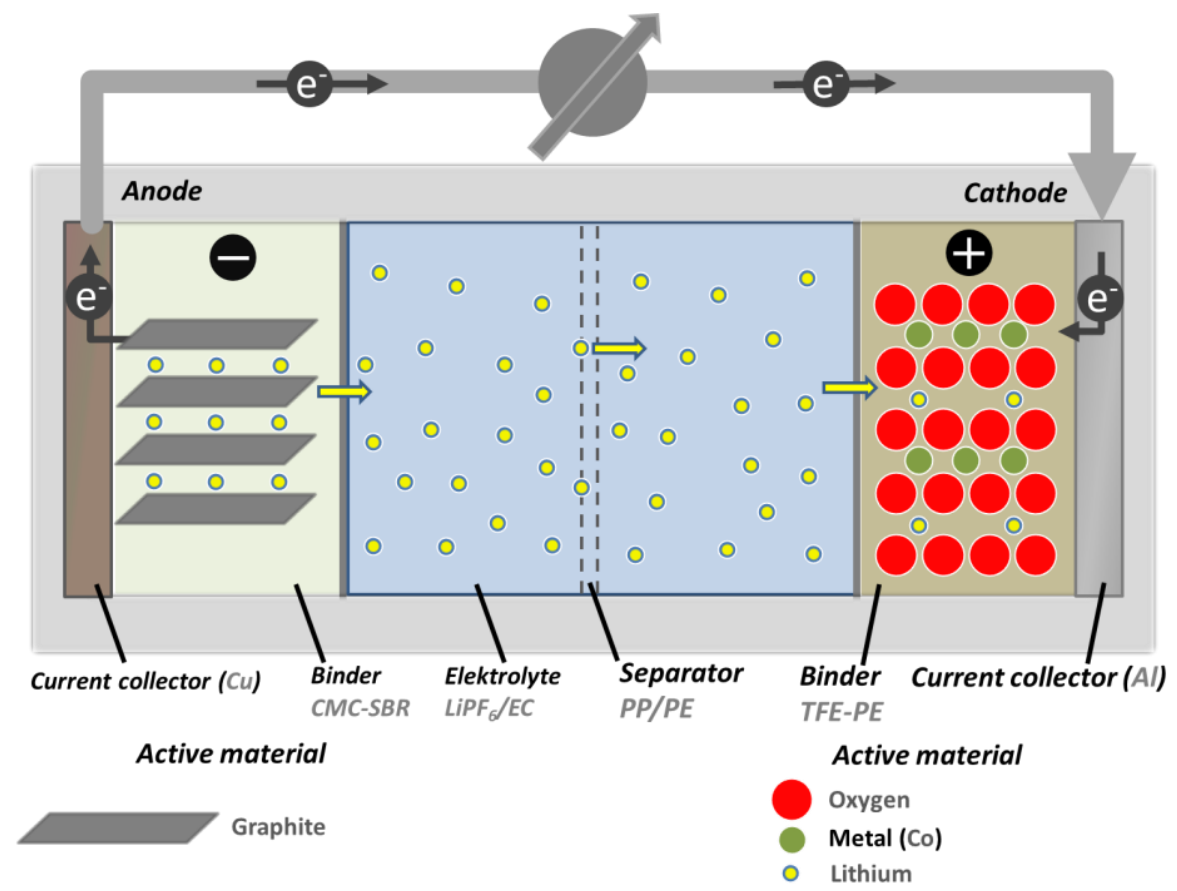

Figure 1: Main components of a LCO battery cell in discharging mode (Peters and Weil, 2016).

Which functional materials are involved? Most of the currently available batteries use graphite, or more accurately, a graphite-lithium intercalation compound as anode with copper as current collector. The only other option at present is lithium titanate, $\mathrm{Li}_{4} \mathrm{Ti}_{5} \mathrm{O}_{12}$, with aluminium as a collector. This anode material shortens the charging time. The higher electrochemical potential of lithium titanate in comparison to the graphite anode drastically reduces, however, the energy density. This anode is therefore mainly used in power tools or hybrid electric vehicles, where power density is more important. On the cathode side a greater variety of elemental composition is encountered. The cathode material determines largely the specific energy and energy density, the cell voltage and the lifetime. For all cathode materials an important factor is the maximum usable amount of lithium that can be mobilized without permanently damaging the crystalline structure of the oxide cathode. The cathode materials are typically abbreviated with three letters, which are also often used to designate the type of battery. Thus, LCO stands for lithium cobalt oxide $\left(\mathrm{LiCOO}_{2}\right)$, which was introduced commercially in 1991 as the first major lithium ion battery technology (Yoshino, 2012). Table 1 gives an overview of some of the more common Li-ion battery types that are used, or have been used, in the transport sector. The list serves as the basis for the analysis in the present paper. Although LCO batteries have a high energy density, the high price of cobalt and political problems associated with its supply led at an early stage to the development of alternative cathode materials for high energy density and long lifetime, but containing little or no cobalt. The lithium manganese oxide (LMO) battery with composition $\mathrm{LiMn}_{2} \mathrm{O}_{4}$ came on the market about five years later. In the NMC battery, on the other hand, the cobalt is only partially substituted by nickel and manganese; in principle any combination $\mathrm{LiNi}_{x} \mathrm{Mn}_{y} \mathrm{Co}_{1-x-y} \mathrm{O}_{2}$ of the three metals is possible. Most common and considered in this article is NMC333, also designated NMC111, which is short for $\mathrm{LiNi}_{1 / 3} \mathrm{Mn}_{1 / 3} \mathrm{Co}_{1 / 3} \mathrm{O}_{2}$. NMC batteries are already of great importance in the transport sector. A further possibility is lithium nickel cobalt aluminium oxide (NCA), a layer system with the stoichiometry $\mathrm{LiNi}_{0.8} \mathrm{Co}_{0.15} \mathrm{Al}_{0.05} \mathrm{O}_{2}$. The last example is 
lithium iron phosphate $\left(\mathrm{LiFePO}_{4}\right)$, a cathode material for which energy density is sacrificed to some extent in order to achieve better safety properties and lower production costs. This cathode material is also used with a lithium titanate anode, leading to the two designations LFP-C and LFP-LTO. Sometimes, in particular in more fundamental electrochemical studies, the various cathode materials are also classified and discussed in terms of their structure: "olivine" (LFP), "layered" (LCO, NMC, NCA) or "spinel" (LMO) (Ghadbeigi et al., 2015; Goodenough and Park, 2013; Nitta et al., 2015; Park et al., 2011).

Table 1: Common commercial battery types and the electrochemical properties for representative, but specific cells based on corresponding references (Nitta et al., 2015; Sterner and Stadler, 2014).

\begin{tabular}{|c|c|c|c|c|c|c|}
\hline Type & $\begin{array}{l}\text { Cathode } \\
\text { active material }\end{array}$ & $\begin{array}{l}\text { Anode } \\
\text { active } \\
\text { material }\end{array}$ & $\begin{array}{l}\text { Potential } \\
\text { cathode } \\
\mathrm{Li} / \mathrm{Li}^{+} \\
\text {(V) } \\
\text { (Nitta et al., } \\
2015 \text { ) }\end{array}$ & $\begin{array}{l}\text { Usable Li } \\
\text { share } \\
\text { (Sterner and Stadler, } \\
\text { 2014) }\end{array}$ & $\begin{array}{l}\text { Specific } \\
\text { capacity } \\
\text { (Ah/kg } \\
\text { cathode) } \\
\text { (Nitta et al., } \\
2015 \text { ) }\end{array}$ & $\begin{array}{l}\text { Specific } \\
\text { energy } \\
\text { (Wh/kg } \\
\text { cathode) } \\
\text { (calculated) }\end{array}$ \\
\hline LCO-C & $\mathrm{LiCoO}_{2}$ & graphite & 3.8 & $55 \%$ & 150 & 570 \\
\hline LMO-C & $\mathrm{LiMn}_{2} \mathrm{O}_{4}$ & graphite & 4.1 & $80 \%$ & 120 & 492 \\
\hline NCA-C & $\mathrm{Li}\left(\mathrm{Ni}_{1-x-y} \mathrm{Co}_{x} \mathrm{Al}_{y}\right) \mathrm{O}_{2}$ & graphite & 3.7 & $70 \%$ & 200 & 740 \\
\hline NMC-C & $\begin{array}{l}\mathrm{Li}\left(\mathrm{Ni}_{\mathrm{x}} \mathrm{Mn}_{\mathrm{y}} \mathrm{CO}_{1-\mathrm{x}-}\right. \\
{ }_{2} \mathrm{OO}_{2}\end{array}$ & graphite & 3.7 & $66 \%$ & 170 & 629 \\
\hline LFP-C & $\mathrm{LiFePO}_{4}$ & graphite & 3.4 & $95 \%$ & 165 & 561 \\
\hline $\begin{array}{l}\text { LFP- } \\
\text { LTO }\end{array}$ & $\mathrm{LiFePO}_{4}$ & $\mathrm{Li}_{4} \mathrm{Ti}_{5} \mathrm{O}_{12}$ & 3.4 & $95 \%$ & 165 & 305 \\
\hline
\end{tabular}

In addition to the widely used battery types NMC, NCA and LFP, a new class of lithium-rich layered oxide cathode has recently been introduced, which can be described as a blend of $\mathrm{Li}_{2} \mathrm{MnO}_{3}$ and $\mathrm{LiMO}_{2}$ ( $\mathrm{M}=$ one or more transition metal) (Yu and Zhou, 2013). The increased lithium content in the cathode potentially increases the charge carrier density and thus the capacity of the battery.

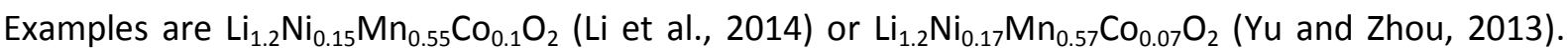
Another strategy to increase energy density is to increase the voltage instead of the specific capacity, which in theory is possible with $\mathrm{LiNiMnO}_{4}$, a lithium spinel structure where manganese is partially substituted by nickel (Kim et al., 2012). These latter devices are mentioned here to demonstrate that the field is very much under development (Andre et al., 2015); they are not included in the present analysis. We also do not consider all-solid-state batteries (Troy et al., 2016).

From this discussion we conclude that supply risks associated with one or more of the ten elements lithium, aluminium, titanium, manganese, iron, cobalt, nickel, copper, carbon (graphite) and phosphorous could, in turn, cause supply risks for one or more of the various lithium ion battery technologies. Lithium is necessary for all battery types in the cathode active material (and is also contained in the electrolyte), but has a by far lower mass contribution; in the case of LFP-LTO it is also present in the anode active material. Carbon, in the form of natural graphite, is used for all anodes with the exception of LFP-LTO. Aluminium is employed in the NCA cathode and in current collectors of all types. Titanium is only contained in the LTO anode. Iron is only employed in the LFP cathode; this is true for phosphorous as well, but it is also a component of the electrolyte. Manganese, nickel and cobalt are important for one or more cathode active materials. Copper is the current collector material for all graphite anodes (Peters and Weil, 2016). 
How have supply risks been treated in the past in resource studies of Li-ion batteries, in particular their cathode materials? For so-called green energy storage Arbabzadeh et al. (Arbabzadeh et al., 2016) have formulated twelve principles relevant to the design of material-intensive electrical grid components. One of these is that the use of critical materials should be minimized. (The term "critical" is sometimes used for elements, for which it is perceived that supply risk problems exist, or could develop, in coming years. As already implied by Footnote 1 , there is unfortunately no accepted definition of what exactly constitutes a "critical" material (Bradshaw et al., 2013; Frenzel et al., 2017). One might perhaps observe that its precise meaning is a part of ongoing research (Graedel and Reck, 2016).) Previous resource studies of the material requirements for Li-ion batteries have focused mainly on the total future demand for applications in the transport sector as well as on the environmental impact of various battery types. Thus, Gaines and Nelson (Gaines and Nelson, 2009) estimated in a relatively early paper the lithium demand from electric vehicles in the United States until $\mathbf{2 0 5 0}$ for four battery technologies. They addressed questions such as the availability of lithium (reserves and reserve base), the possibility of formation of new cartels and the existence of other supply constraints. Delucchi et al. (Delucchi et al., 2013) listed aspects such as reserves, resources, recycling and material costs for selected vehicle battery type materials. They concluded that there are at least two lithium-ion battery technologies, $\mathrm{LiMn}_{2} \mathrm{O}_{4}$ and $\mathrm{LiFePO}_{4}$, that "do not use scarce or expensive materials, assuming that the lithium production and recycling industries develop as might be expected". Ghadbeigi et al. (Ghadbeigi et al., 2015) performed a more material-oriented survey of the lithium-ion battery literature, but included the resource-oriented indicators "static reach" and Herfindahl-Hirschman "concentration index" in their analysis. In a revised version of an earlier report "Raw Materials for Emerging Technologies" (in German) Marscheider-Weidemann et al. (Marscheider-Weidemann et al., 2016) have created scenarios for global raw material demand in 42 emerging technologies. On the assumption that a market breakthrough for battery electric vehicles will have occurred by 2035, they concluded that there would have to be on average a $7.5 \%$ annual growth rate in the production of lithium, and a $3.0 \%$ growth rate in that of cobalt in order to satisfy demand from electric vehicles alone. A similar, but more detailed study, by Simon et al. (Simon et al., 2015), covering five different Li-ion battery types, has come to similar conclusions. These authors emphasized in particular the limited reserves of lithium and nickel and the possible role of resource depletion in coming decades. Peters and Weil (Peters and Weil, 2016) are more conservative in their estimates. In contrast to the above supply risk assessments, they quantified resource depletion by using the characterization factors from six different Life Cycle Impact Assessment (LCIA) methodologies. The results from the various assessments were very non-uniform and the authors concluded that all the methods have some major drawback that influences negatively the result obtained. By considering only the active materials used for the electrodes and collectors was it possible to ascertain with most methodologies an advantage for LFP that is probably due to the absence of "critical" materials such as cobalt and nickel (Peters and Weil, 2016). We note that all of the impact categories used in these techniques are essentially long-term indicators, whereas supply risk assessments in the present paper (and in those of several previous authors, e.g. Simon et al. (Simon et al., 2015)) also take into account the short- to mid-term risks associated with the material requirements of a technology. Peters and Weil (Peters and Weil, 2016) point out that one of the problems for LCA-related resource studies is an on-going discussion on the meaning (and estimation) of the resource depletion potential. This issue has also been recently discussed by Dewulf et al. (Dewulf et al., 2015). Moreover, it should be noted that in resource studies in general some doubt always exists as to the real extent of reserves and resources, since the economic viability of extraction plays an important role in the definition of these two concepts. 
In LCIA studies in general, resource depletion aspects form only one part of the evaluation, alongside the more widely used aspects of human health and ecosystem quality. Thus, Majeau-Bettez et al. (Majeau-Bettez et al., 2011) and Zackrisson et al. (Zackrisson et al., 2010), compare the environmental impacts of different electric vehicle battery types. Similarly, Reuter (Reuter, 2016a, 2016b) has compared NMC and LFP batteries according to different sustainability criteria in the three categories often associated with the concept of sustainability, namely, "environmental", "economic" and "social". In the first category he has employed LCIA techniques for an emissions assessment (greenhouse gases, acidification potential, eutrophication potential) and material flow analysis for resource depletion. To assess supply risk in the second category, Reuter used a weighted average of the supply risks scores from a report of the European Commission (European Commission, 2014), which includes the indicators "market concentration", "political stability", "substitutability" and "recyclability". On the environmental side, but outside the LCIA formalism, Diekmann et al. (Diekmann et al., 2017) have recently compared the merits of various recycling schemes for Li-ion batteries and have also described a new "ecological" recycling procedure. The latter is characterized by a mainly mechanical process followed by a hydrometallurgical treatment to recover the electrode materials. Wang et al. (Wang et al., 2014) also pointed out the importance of cathode active material composition for later recycling opportunities, but in the current phase of technological development, large-scale waste streams to cover the raw material requirements are not available.

\section{Method}

The evaluation method used in this article to assess the supply risks associated with the materials used in different lithium-ion battery chemistries (referred to as "technologies" in this article) follows the approach presented in previous articles by the authors (Helbig et al., 2016; Tuma et al., 2014). Firstly, it evaluates the relative supply risk of the individual elements constituting the functional materials in various lithium-ion batteries ( $\mathrm{Li}, \mathrm{Al}, \mathrm{Ti}, \mathrm{Mn}, \mathrm{Fe}, \mathrm{Co}, \mathrm{Ni}, \mathrm{Cu}, \mathrm{P}$, graphite) specifically for the case of lithium-ion batteries. Secondly, it goes on to aggregate the supply risk "scores" at the technology level for six battery systems, as shown in Table 1 (LCO-C, LMO-C, NMC-C, NCA-C, LFP-C and LFP-LTO). Not considered in the evaluation are oxygen and non-graphitic carbon, as well as other materials in polymers and the battery management system. In contrast to the previous application to thin-film photovoltaics (Helbig et al., 2016), there is a significant overlap of the elements in the evaluated technologies: lithium and aluminium are contained in all Li-ion battery technologies; copper is contained in all technologies that use a graphite anode (i.e. all except LFP-LTO). Moreover, six technologies are compared, rather than only two in the case of thin-film photovoltaics.

The essential features of our assessment procedure are shown schematically in the hierarchical diagram of Figure 2. The relative supply risk for the elements is considered to be composed of four general supply risk criteria: (i) risk of supply reduction, (ii) risk of demand increase, (iii) concentration risk and (iv) political risk. The risk criteria consist of two or three indicators each, the sources for which include the scientific literature, reports and various databases. These data include global sums for the material flows, descriptions of the technical properties of each element, country-specific production tonnages and appraisals at the company and country levels in political and social matters. The risk of supply being unable to match demand due to supply reduction is estimated using three indicators: the static reach of the reserves, the static reach of the resources and, as a risk-reducing factor, the end-of-life recycling rate of the element. The supply risk due to demand increase is made up of the indicators: by-product dependence in the primary production of the element, estimated future technology demand and lack of substitutability. The concentration risk is calculated using both 
the country concentration and the company concentration, meaning the tendency for formation of monopolies and cartels. The political risk is estimated by the indicators political stability, so-called policy perception and the risk of introduction of further regulatory measures (all in the producing countries, where mining, smelting or refining happen). The selection of indicators is based on an analysis of existing supply risk assessments (Achzet and Helbig, 2013; Tuma et al., 2014). The Supplementary Material (Tables S1, S2) also contains more detailed descriptions of each indicator, information on the calculation and normalization of the indicator-specific "score", or rating, and data sources for the origin and application of such indicators in previous studies. Similarly, the normalisation of each indicator onto a common scale of 0 (lowest supply risk) to 100 (highest supply risk) is carried out in the same way as presented in our previous article on thin-film photovoltaic supply risks (Helbig et al., 2016) Note, again, that these "final" numbers are relative supply risk scores, i. e. they are only to be compared with other supply risk scores derived in the context of this article. They are not estimates of the absolute likelihood of supply being unable to meet demand within a specific risk scenario.

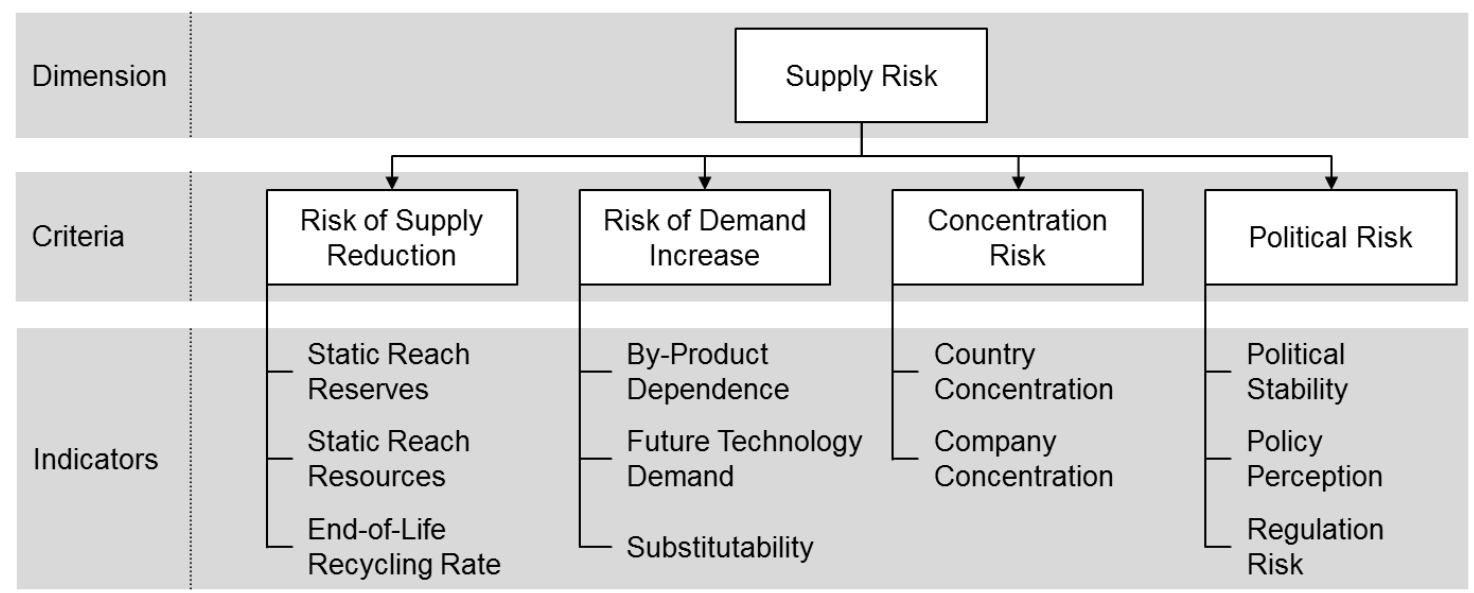

Figure 2: Supply risk criteria and indicators used for the supply risk assessment, after (Tuma et al., 2014).

In order to weight the four risk criteria and the eleven indicators for the specific case of lithium-ion batteries ten international experts were asked to participate in an Analytic Hierarchy Process (AHP) (Saaty, 2008). AHP is a well-established method for solving multi-criteria decision problems based on pairwise comparisons of evaluation criteria. The AHP questionnaire sent to the experts and more details on the experts' background is given in the Supplementary Material (Figure S1 to S3) and the results, namely, the weighted supply risk scores, are given in Section 4 below. These are then subject to a sensitivity analysis for each of the ten elements, in which they are compared with the scores from two alternative weightings: "criteria weighting", in which all four risk criteria are weighted equally and "equal weighting", in which all eleven indicators are given the same weight.

The choice of indicators also determines the time-scale on which the perceived supply risk is considered to pertain. Some indicators refer to the present or to the very recent past, e.g. end-of-life recycling rate, by-product dependence or those indicators characterising political risk. Others, such as the static reaches or the future technology demand, extend at least for several decades into the future. The result of the present analysis is thus a determination of supply risk on a short to medium term basis. If, for instance, current mineral prices were also to be used as an indicator then the overall assessment would be anchored more strongly in the present - depending of course on the weighting given to it in the AHP procedure.

In a second step we determine the supply risk score on the so-called technology level, i.e. for each of the six different battery types listed in Table 1, by aggregating the results for the individual elements. 
Four possibilities were identified in our previous work on photovoltaic materials (Helbig et al., 2016): the simple arithmetic mean, the arithmetic mean with mass-share weighting, the arithmetic mean with cost-share weighting and the "maximum" approach. For the simple arithmetic mean, each element has the same weighting for the calculation. Mass-share weighting considers each element according to the contribution of its mass; cost-share weighting takes into account both its mass and the raw material costs. The maximum method considers only the element with the highest supply risk score. In order to determine the supply risks with mass-share weighting and cost-share weighting it is necessary to know the material composition for each battery technology. We have used the data from Peters and Weil (Peters and Weil, 2016) based on various life cycle inventories (Bauer, 2010; Ellingsen et al., 2014; Majeau-Bettez et al., 2011; Notter et al., 2010; Zackrisson et al., 2010), complemented by data from Lu et al. (Lu et al., 2016) for LCO-C. Raw material costs are taken from the "BGR DERA Preismonitor" (DERA, 2016) and are listed in the Supplementary Material (Table S20). The sensitivity analysis is subsequently applied to the aggregated supply risks on the technology level, as in the case of the ten elements.

The last step in the procedure is to perform Monte Carlo-based simulations in order to determine the effect of uncertainty distributions in the input data used. More details are given in the Supplementary Material (Table S21). The result is a so-called box plot demonstrating the possible overlap of supply risk scores (Figure 7 and Figure S7).

\section{Results}

\subsection{Supply risk data}

As explained in the previous section, the supply risk assessment starts with the determination of the values of all eleven indicators for each of the ten elements under consideration. It is not necessary at this point to describe or discuss the physical or chemical properties of these elements. We simply note that eight of the elements are metals; phosphorous and graphite (carbon) are non-metals. In the periodic table, $\mathrm{Ti}, \mathrm{Mn}, \mathrm{Fe}, \mathrm{Co}, \mathrm{Ni}$ and $\mathrm{Cu}$ are all first-row transition metals. $\mathrm{Li}$ is the lightest alkali metal; $\mathrm{Al}$ is a so-called post-transition metal. Except for lithium and cobalt (see below), most of the elements are mined in their own right. Further, we recall that mining activity is often reported in terms of tonnage of the corresponding mineral or ore: $\mathrm{Al}$ is mined as bauxite, $\mathrm{P}$ as phosphate, $\mathrm{Ti}$ as ilmenite or rutile (USGS, 2016). Table 2 gives a summary of the indicator values, or supply risk scores, in the units as calculated. More details and explanatory notes can be found in the Supplementary Material (Table S3 to S18). Since most of these materials are either mass-produced with high tonnages or their extraction is already subject to political scrutiny (cobalt, for example, is considered as a "conflict mineral" (Cunningham, 2014)), information on production figures, as well as on reserve and resource estimates are readily available (USGS, 2016). 
Table 2: Supply risk indicators on the elemental level before normalization. For explanations of the indicators and further information on assumptions concerning the data, see Supplementary Material (Table S3 to S18).

$\bigoplus$ : Higher figures indicate higher risk. $\ominus$ : Lower figures indicate higher risk.

\begin{tabular}{|c|c|c|c|c|c|c|c|c|c|c|c|c|}
\hline Indicator & Dimension & Risk & $\mathrm{Li}$ & Al & $\mathrm{Ti}$ & $\mathrm{Mn}$ & $\mathrm{Fe}$ & Co & $\mathrm{Ni}$ & $\mathrm{Cu}$ & C & $\begin{array}{l}\mathrm{P} / \mathrm{PO} \\
4\end{array}$ \\
\hline $\begin{array}{l}\text { Static Reach } \\
\text { Reserves }\end{array}$ & years & $\ominus$ & $431 a$ & $102 a$ & $130 a$ & $34 a$ & $26 a$ & $57 a$ & $31 a$ & $39 a$ & $193 a$ & $309 a$ \\
\hline $\begin{array}{l}\text { Static Reach } \\
\text { Resources }\end{array}$ & years & $\ominus$ & $\begin{array}{l}1252 \\
a\end{array}$ & $201 a$ & $328 a$ & $\begin{array}{l}>200 \\
a\end{array}$ & $69 a$ & $\begin{array}{l}1169 \\
a\end{array}$ & $51 a$ & $303 a$ & $672 a$ & $\begin{array}{l}1300 \\
a\end{array}$ \\
\hline $\begin{array}{l}\text { EoL-Recycling } \\
\text { Rate }\end{array}$ & $\%$ & $\ominus$ & $1 \%$ & $60 \%$ & $1 \%$ & $53 \%$ & $67 \%$ & $68 \%$ & $58 \%$ & $53 \%$ & $0 \%$ & $0 \%$ \\
\hline $\begin{array}{l}\text { By-Product } \\
\text { Dependence }\end{array}$ & $\%$ & $\oplus$ & $\begin{array}{l}52 \% \\
(\mathrm{~K})\end{array}$ & $0 \%$ & $0 \%$ & $3 \%$ & $1 \%$ & $\begin{array}{l}85 \% \\
(\mathrm{Ni}, \\
\mathrm{Cu})\end{array}$ & $2 \%$ & $9 \%$ & $0 \%$ & $0 \%$ \\
\hline $\begin{array}{l}\text { Future } \\
\text { Technology } \\
\text { Demand }\end{array}$ & $\%$ & $\oplus$ & $390 \%$ & $0 \%$ & $0 \%$ & $0 \%$ & $0 \%$ & $90 \%$ & $0 \%$ & $0 \%$ & $0 \%$ & $0 \%$ \\
\hline Substitutability & qualitative & $\ominus$ & 59 & 56 & 37 & 4 & 43 & 46 & 38 & 30 & 28 & 3 \\
\hline $\begin{array}{l}\text { Country } \\
\text { Concentration }\end{array}$ & $\mathrm{HHI}$ & $\oplus$ & 3195 & 3244 & 862 & 1818 & 2562 & 2808 & 1126 & 1666 & 4579 & 2563 \\
\hline $\begin{array}{l}\text { Company } \\
\text { Concentration }\end{array}$ & $\mathrm{HHI}$ & $\bigoplus$ & 1664 & 2221 & 1317 & 1357 & 837 & 1902 & 1191 & 1108 & 4760 & 2239 \\
\hline WGI_PV & qualitative & $\ominus$ & 0.59 & -0.17 & -0.07 & -0.01 & -0.01 & -1.13 & -0.10 & 0.03 & -0.50 & -0.36 \\
\hline PPI & qualitative & $\theta$ & 79 & 60 & 57 & 57 & 61 & 51 & 56 & 66 & 49 & 55 \\
\hline HDI & qualitative & $\oplus$ & 0.86 & 0.76 & 0.71 & 0.73 & 0.79 & 0.59 & 0.75 & 0.77 & 0.72 & 0.74 \\
\hline
\end{tabular}

\subsubsection{Risk of supply reduction}

The static reaches of the reserves of the ten elements range from low values of 26 years for iron and 31 years for nickel to 309 years for phosphate and 431 years for lithium. Nickel and iron also have the lowest values for the static reach of the resources (51 years and 69 years, respectively), with Li, Co and $\mathrm{P}$ showing values above 1000 years. As we have noted in our previous article (Helbig et al., 2016), static reaches give a measure of both the market pressure for further mineral prospecting and of subsequent mining activity, not of actual physical depletion. End-of-Life recycling rates are above $50 \%$ for $\mathrm{Al}, \mathrm{Mn}, \mathrm{Fe}, \mathrm{Co}, \mathrm{Ni}$ and $\mathrm{Cu}$. On the other hand, the recycling rates for lithium, titanium, graphite and phosphate are negligible. While lithium has its main applications in batteries as well as in ceramics and glasses, titanium is mainly used as a white pigment in the form of titanium dioxide. Graphite is an important material for electrodes and refractories; phosphorous is a key fertilizer and also feedstock in the chemical industry (European Commission, 2014; Graedel et al., 2015). All of these applications are either dissipative or produce irrecoverable waste streams (Ciacci et al., 2015).

\subsubsection{Risk of demand increase}

Among the ten elements evaluated, by-product dependence is only a problem for lithium (about half of the extracted tonnage is a by-product in potassium production) and cobalt (which is a by-product of $\mathrm{Ni}$ and $\mathrm{Cu}$ ). All other elements show values below $10 \%$ by-product dependence. As mentioned in Section 2, Marscheider-Weidemann and colleagues (Marscheider-Weidemann et al., 2016) have recently updated a previous study on future technology demand (Angerer et al., 2009) and estimated the requirements for key materials in 42 identified future technologies in 2035. In our set of ten elements, a substantial future demand was only identified for lithium and cobalt with growths of 
390\% and 90\%, respectively, compared to production in 2013 (Marscheider-Weidemann et al., 2016). An increase in use of the eight other elements for rapidly evolving future technologies could occur as well, but not on a large scale. The ease of substitutability of manganese has been rated very low, as there is no other metal available with the same metallurgical properties. Phosphorous is an essential fertilizer for which there is no substitute. Interestingly, the highest overall level of substitutability (i.e. in all applications, not only batteries) among the ten elements is shown by lithium, since there are other elements available as active materials for rechargeable and primary batteries as well as for ceramics, glasses and lubricating greases (Graedel et al., 2015).

\subsubsection{Concentration risk}

Market concentration is measured at the company level as well as at the national level. On the Herfindahl-Hirschman-Index (HHI) scale ranging from 0 to 10000 the country-based concentration of production is low for titanium (HHI 862) and nickel (HHI 1126) (USGS, 2016). The highest country concentration is observed for graphite ( $\mathrm{HHI} 4579$ ) which is mainly produced in China (USGS, 2016). Graphite also has the highest company concentration with an HHI of 4760 (Buchholz et al., 2015). Iron, copper and nickel have low concentration values around HHI 1000 (Buchholz et al., 2015).

\subsubsection{Political risk}

Political risk is determined by an evaluation of political stability in producing countries according to three distinct categories: stability, the perception of policy towards mining and the possibility of stronger regulation. As lithium is primarily produced in Australia and Chile (USGS, 2016), two rather stable and mining-friendly countries, this metal has the highest scores for the Worldwide Governance Indicators, the Policy Perception Index and the Human Development Index. In contrast, about half the global production of cobalt is located in the Democratic Republic of the Congo (USGS, 2016), which receives low evaluation scores for all three indicators.

\subsection{Normalization \& weighting}

As described in our previous papers (Helbig et al., 2016; Tuma et al., 2014), the next step is to normalize the values of each indicator to a common scale and then to apply the weighting for the specific case of lithium-ion batteries. The supply risk scores for the eleven indicators for each of the ten elements following the normalization are shown in Table S18 of the Supplementary Material. Figure 3 shows the same data in the form of a diagram. High values up to 100 indicate high supply risk. The range of values obtained after normalization in the two categories concentration risk and political risk is narrow. In the categories risk of supply reduction and risk of demand increase, values for the ten elements can differ by more than 50 points on the $0-100$ on the supply risk scale.

Lithium has the highest supply risk with respect to the Human Development Index and future technology demand. Cobalt has the highest supply risk for the Worldwide Governance Indicators and the by-product dependence. Iron has the shortest static reach for reserves, nickel the shortest static reach for resources. The elements lithium, titanium, graphite and phosphorous are not recycled at all. Substitutability is lowest for manganese and phosphorous. Graphite has the highest country concentration, the highest company concentration and the highest risk from the viewpoint of the Policy Perception Index. For both static reaches, the by-product dependence and the future technology demand, several elements show no risks at all. Cobalt has the highest end-of-life recycling rate and Human Development Index scores. Lithium has the highest substitutability value, and the highest Worldwide Governance Indicator and Policy Perception Index scores. Titanium has the lowest country concentration and iron the lowest company concentration. 


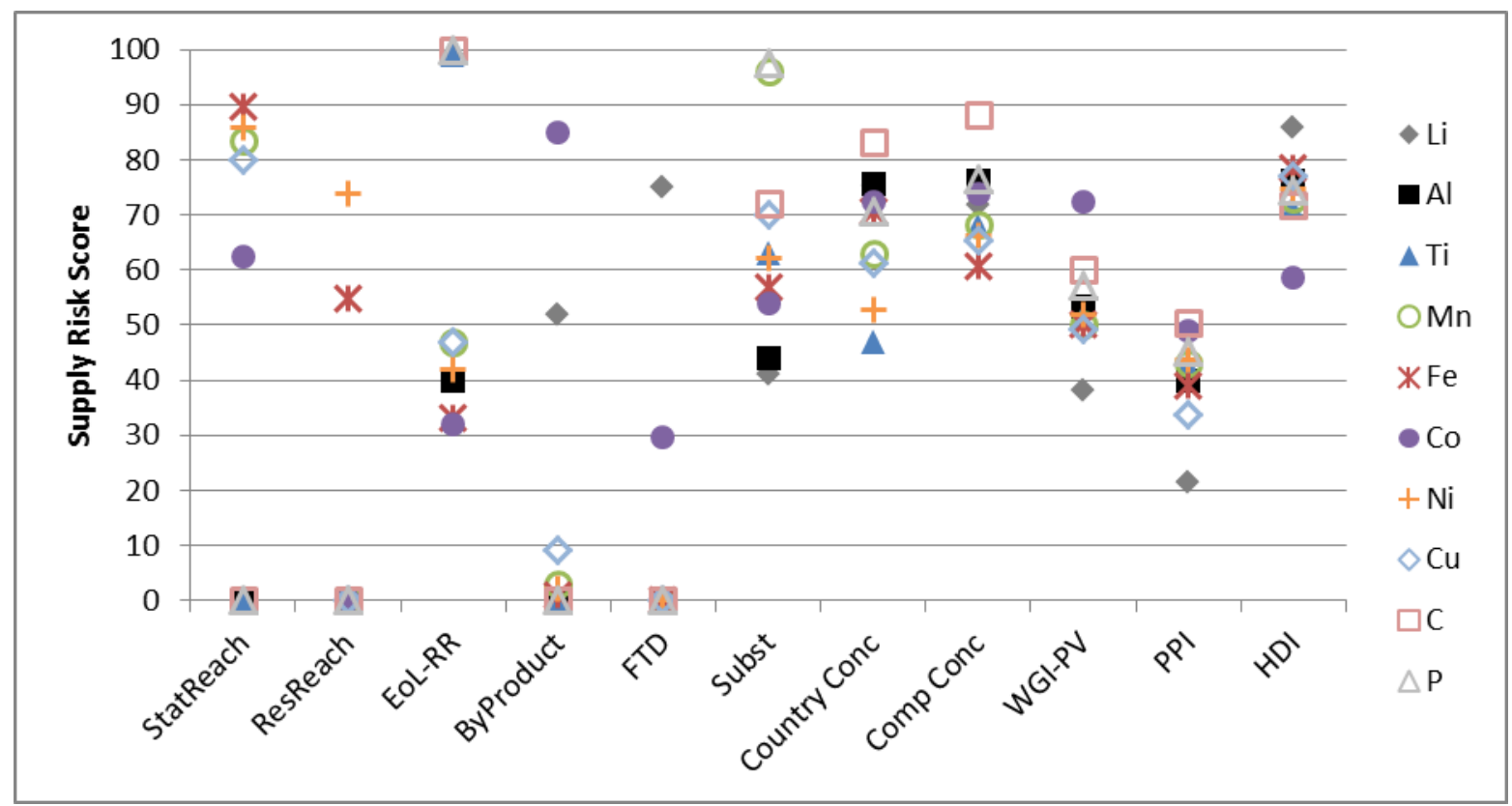

Figure 3: Supply risk values for all eleven indicators and all ten elements after normalization.

The analysis of the results from the questionnaires in the Analytic Hierarchy Process (AHP) leads to a weighting of the eleven indicators. Ten invited experts participated in the weighting process and were asked to consider specifically the situation of Li-ion battery technologies. The consistency ratio of the mean evaluation of all experts results in values below the threshold, so that the resulting weightings can be used. The results are shown in Table 3. The highest single indicator weighting was assigned to substitutability (14.2\%), just ahead of future technology demand (14.1\%). Country concentration (13.0\%) and political stability (11.2\%) also received above-average weightings. The lowest weighting was assigned by the experts to the by-product dependence (3.9\%) and to the remaining two indicators in the political risk category: policy perception (5.2\%) and regulation risk (5.3\%). 
Table 3: Indicator weighting according to the expert-based Analytic Hierarchy Process (AHP). For details of the AHP, see Supplementary Material (Figure S1 to S3).

\begin{tabular}{lll} 
Criterion & Indicator & Weighting \\
\hline Risk of Supply Reduction & Static Reach Reserves & $8.9 \%$ \\
\hline & Static Reach Resources & $5.2 \%$ \\
\hline Risk of Demand Increase & End-of-Life Recycling Rate & $9.2 \%$ \\
\hline & By-Product Dependence & $3.9 \%$ \\
\hline Concentration Risk & Future Technology Demand & $14.1 \%$ \\
\hline & Substitutability & $14.2 \%$ \\
\hline Political Risk & Country Concentration & $9.7 \%$ \\
\hline & Company Concentration & $13.0 \%$ \\
\hline & Political Stability & $11.2 \%$ \\
\hline
\end{tabular}

\subsection{Supply risk on the elemental level}

Following normalization and weighting, the aggregation of the indicator values give the relative supply risk scores for each of the ten elements ( $\mathrm{Li}, \mathrm{Al}, \mathrm{Ti}, \mathrm{Mn}, \mathrm{Fe}, \mathrm{Co}, \mathrm{Ni}, \mathrm{Cu}, \mathrm{C}$ and $\mathrm{P}$ ), as shown in Figure 4. Lithium and cobalt (both 54 - we refer to these as "points") have the highest supply risk scores. Aluminium shows the lowest (39 points) followed by the second lowest, titanium (43 points). The latter both have zero supply risk associated with the static reach for reserves, the static reach for resources, the by-product dependence and the future technology demand, which explains the low overall supply risk. They share these four scores with phosphorous (which has very high supply risk scores for recycling and substitutability). The high score for lithium emerges from a lack of end-of-life recycling, the high future technology demand and the regulation risk. The high supply risk score of cobalt, in contrast, results from the by-product dependence and the high risk from political instability. Copper (48 points), iron (49 points), nickel (50 points), graphite, manganese (both 52 points) and phosphorous (53 points) form the middle group.

Other options such as equal weighting, criteria weighting, or the application of the weightings of the previous AHP analysis from thin-film photovoltaics (Helbig et al., 2016) show a similar pattern with only slight differences. For both equal weighting and criteria weighting, cobalt would be the element with the highest supply risk; nickel would have a higher supply risk than manganese and phosphorous. We will retain the weightings from the present AHP analysis here in the main article. The sensitivity analysis in the Supplementary Material (Figure S4 to S6) shows the alternative results for these other weighting options. 


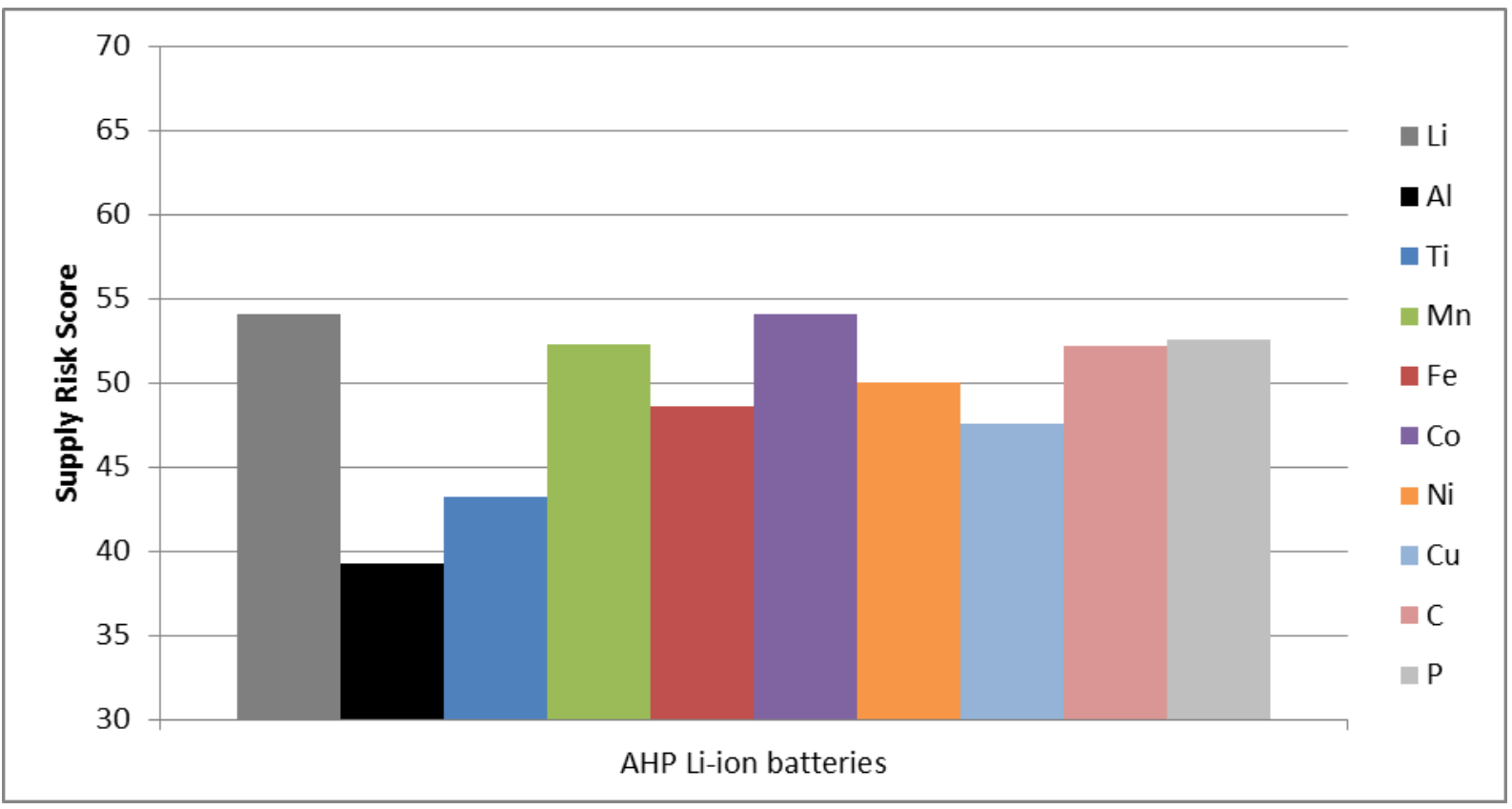

Figure 4: Elemental supply risks after aggregation of all indicators to a single value using the AHP-determined weightings.

\subsection{Supply risk aggregation on the technology level}

In order to compare the results for different battery types, supply risk scores on the elemental level need to be aggregated to give comparative supply risks on the technology level. The results for the six technologies and ten elements are shown in Figure 5. In the case of the simple arithmetic mean, four technologies (LCO-C, LMC-C, NCA-C, NMC-C) have the same highest supply risk score of 50 points, LFP-C has 49 points and the lowest supply risk score is determined for LFP-LTO with 48 points. The narrow range obtained for this aggregation option is partly due to the fact that Li (active material, electrolyte), Al (cathode current collector) and $\mathrm{P}$ (electrolyte) are common to all technologies. Graphite and $\mathrm{Cu}$ are included in all technologies except LFP-LTO; $\mathrm{Co}$ is contained in three technologies; Ti is only used in LFP-LTO.

When the mass-share approach is applied, the spread of values is somewhat greater. The highest supply risk is obtained for NMC-C (50 points) and the lowest supply risk again for LFP-LTO (45 points). In this approach, the impact of lithium on the supply risk evaluation is reduced due to its low specific mass. It accounts for $6.5 \%$ of the mass in LFP-LTO, but only $1.3 \%$ in LMO-C. Instead, Cu and graphite, which often make up more than a quarter of the mass, become of above-average importance. The same is true for Fe (in the case of LFP-based batteries) and for the transition metals in the active material (Ni for NCA, Mn for LMO, Ti for LTO).

In the case of the cost-share approach, the importance of lithium increases due to high specific costs. Iron and phosphorous are in contrast associated with low costs. In case of LFP-LTO, lithium makes up $72 \%$ of the material costs of the ten elements. Cobalt makes up more than two thirds of the material costs for LCO-C, copper more than half for LMO-C. Overall, this leads to LCO-C having the highest supply risk score ( 53 points) and LMO-C the lowest (49 points).

The fourth aggregation method is the maximum approach, which in this case leads to the same supply risk score for all technologies, since lithium has the highest relative supply risk ( 54 points) of all ten elements and is essential for all of them. 


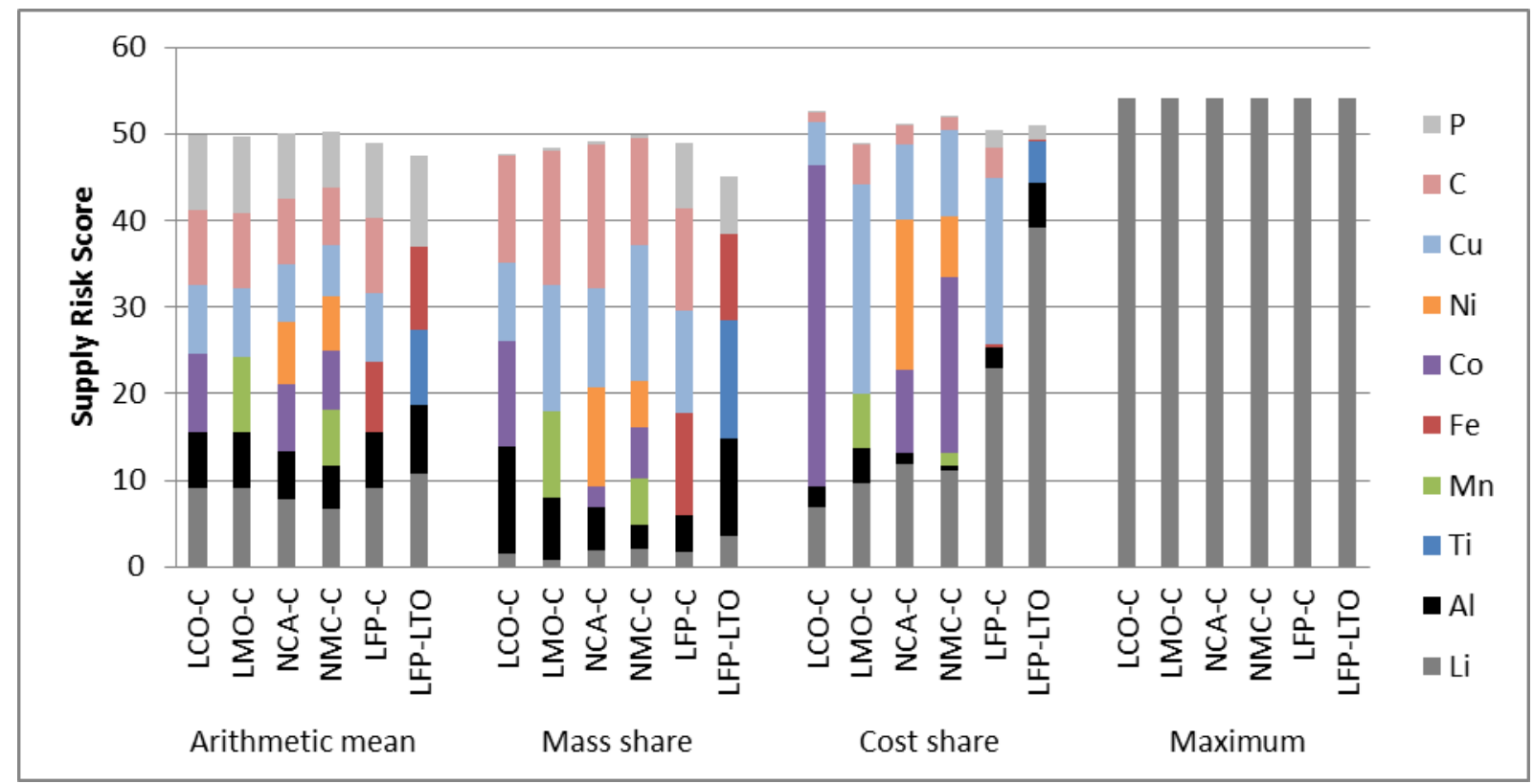

Figure 5: Contribution of each material to the technology-level supply risk score. Results from different aggregation procedures. Arithmetic mean: each element has same weighting. "Mass-share" aggregation: elements are weighted according to their mass share in the battery. "Cost-share" aggregation: elements are weighted according to their raw material cost share. "Maximum" weighting: the element with highest supply risk determines the supply risk for the technology.

A wider range, or spread, in the supply risk scores is achieved if the elements used in all of the technologies ( $\mathrm{Li}, \mathrm{Al}, \mathrm{P})$ are removed from the analysis. Figure 6 thus shows the results if only $\mathrm{Ti}, \mathrm{Mn}$, $\mathrm{Fe}, \mathrm{Co}, \mathrm{Ni}, \mathrm{Cu}$ and graphite are assessed. In this case, the order of technologies in the simple arithmetic mean option is preserved, with LCO-C, LMO-C, NCA-C and NMC-C having the highest supply risk of 51 points and LFP-LTO having the lowest with 46 points. In the mass-share approach, the highest supply risk is observed for LCO-C with 51 points; LFP-LTO has 45 points. In the case of cost-share aggregation, LCO-C has the highest supply risk with 53 points; LFP-LTO also has the lowest supply risk of 43 points (because of the exclusion of Li from the assessment). The largest difference compared to the evaluation of all ten elements is observed for the maximum aggregation approach, where Co with 54 points gives rise to highest supply risk in LCO-C, NCA-C and NMC-C. Note that LFPLTO has the lowest supply risk score in all aggregation options, when the elements $L i, A I$ and $P$ are removed from the assessment. 


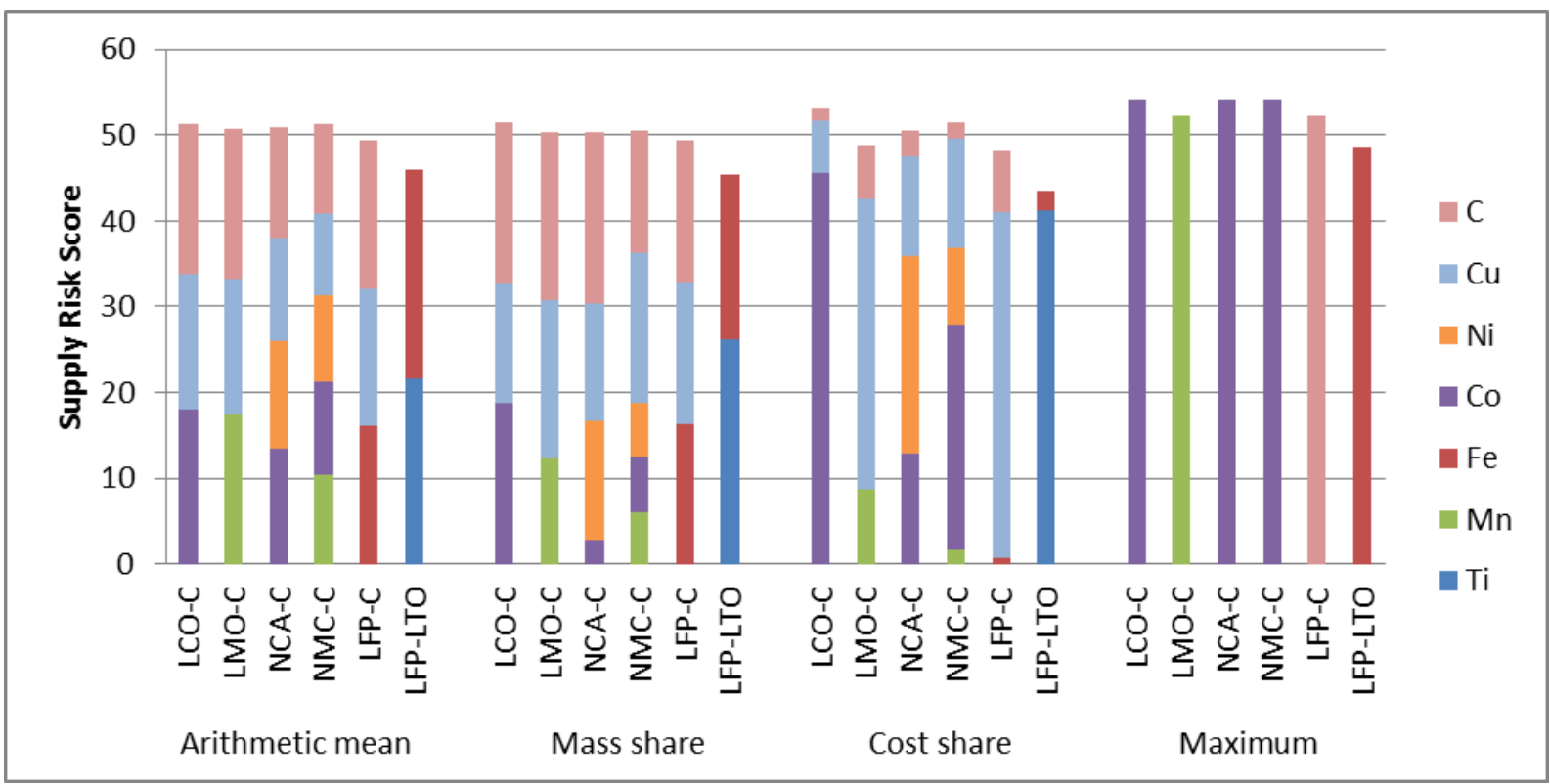

Figure 6: Contribution of each material (without Li, Al, P) to the technology-level supply risk score. Results from different aggregation procedures. Arithmetic mean: each element has same weighting. "Mass-share" aggregation: elements are weighted according to their mass share in the battery. "Cost-share" aggregation: elements are weighted according to their raw material cost share. "Maximum" weighting: the element with highest supply risk determines the supply risk for the technology.

\subsection{Uncertainty analysis}

Most data used for the assessment of supply risk on both the element and technology levels are subject to uncertainty. All data sources are therefore assumed to be characterised with distributions over data type and quality, for which details are listed in the Supplementary Material (Table S21). We have performed a Monte Carlo simulation with 10000 instances of random-number generation on both assessment levels. The results are shown in the box plot of Figure 7, as a statistical summary (mean, median, quartiles, and outliers). The interquartile ranges are usually below five supply risk points, on both the element and technology levels. It can be seen that for some element pairs, e.g. Li and $\mathrm{Co}$, the uncertainty range $\left(25^{\text {th }}\right.$ percentile to $75^{\text {th }}$ percentile) is higher than the difference in mean value, and it would therefore not be justified to identify one of the elements as having a "higher" supply risk. In contrast, on the lower end of the supply risk scale, Al and Ti remain as the elements with the lowest relative supply risk, despite the assumed distributions. On the technology level, despite the generally lower interquartile ranges (e.g., often only 2 points in the case of the simple arithmetic mean), the small differences in the mean values of the six technologies again lead to overlaps of the quartile boxes and therefore in a similar way it would not be possible to conclude that there is - in statistical terms - a "higher" supply risk for one technology compared to another. 


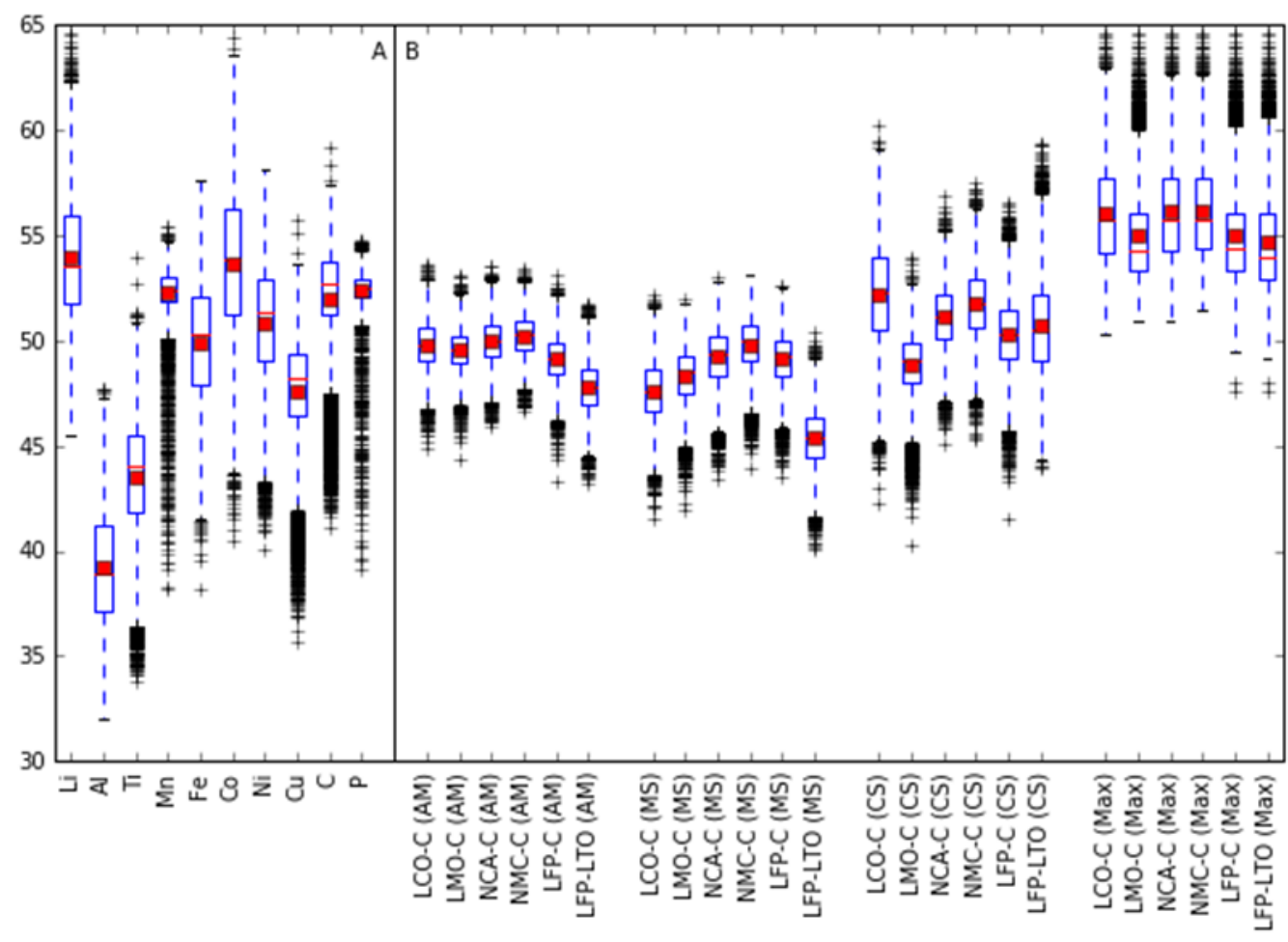

Figure 7: Results of the Monte Carlo simulation with 10000 instances to estimate the uncertainty of the supply risk both on the (A) elemental and (B) technology levels. Arithmetic mean (AM): each element has same weighting. "Mass-share" (MS) aggregation: elements are weighted according to their mass share in the battery. "Cost-share" (CS) aggregation: elements are weighted according to their raw material cost share. "Maximum"

(Max) weighting: the element with highest supply risk determines the supply risk for the technology. Details concerning the estimated data uncertainty are listed in the Supplementary Material (Table S21).

\section{Discussion}

We first consider the data at the elemental level. It is immediately apparent that for the ten elements, the range, or spread, of supply risk values is narrower (Figure 4) than in the case of thin film photovoltaic materials (Helbig et al., 2016). For the seven metals considered in that paper, the supply risk scores range from 48 points $(\mathrm{Cu})$ to 73 points (In), whereas for the ten battery elements in the present work, the corresponding values are 39 points (Al) and 54 points ( $\mathrm{Li}$ and $\mathrm{Co}$ ). They thus lie within a rather narrow band of just 15 supply risk points on a scale from 0 to 100 . (Note that $\mathrm{Cu}$, the only element common to both the present study and the work on photovoltaics materials, has the same supply risk score of 48 points in each, despite the somewhat different weightings of the indicators.) In the present case, Al and Ti both have zero supply risk associated with the static reach for reserves, the static reach for resources, the by-product dependence and the future technology demand, which explains the low overall supply risk. They share these four scores with phosphorous which, on the other hand, has very high supply risk scores for recycling and substitutability. The relatively high score for lithium emerges from a lack of end-of-life recycling, a high future technology demand and the regulation risk. The relatively high supply risk score for cobalt, in contrast, results from the by-product dependence and the high risk from political instability. The aggregate scores for the metals fall in a relatively narrow range, although the contributory individual supply risks that are decisive in each case are of different origin. This appears to be coincidence rather than due to some anomaly of the method. One reason for the much wider range of supply risk scores in the case of the thin film photovoltaic materials was the rather high individual scores for In and Ga. Indium, in particular, has low static reaches and a low end of life recycling rate; it is a by-product, and there is a 
high policy perception risk. A similar, "critical" metal is not present amongst the ten battery metals, a fact which may bode well for the future availability of materials for lithium-ion batteries! However, it is an important result of the present evaluation that lithium and cobalt have the highest supply risk among the evaluated ten elements. Thus a general recommendation resulting from our assessment would be to continue the development of Li-ion technologies in order to decrease the material intensity ( $\mathrm{g} / \mathrm{Wh}$ ) for $\mathrm{Li}$ and perhaps to avoid Co-containing batteries as far as possible, which goes along with earlier recommendations (Simon et al., 2015). Recent fears that cobalt might soon be labelled as a so-called conflict mineral (Amnesty International, 2016) could lead to a political risk that is higher than that calculated in the present assessment.

The first observation to be made from the results at the technology level is that most of the supply risk scores are found in a relatively narrow range. This is particularly the case for the "simple arithmetic mean" and "mass share" techniques. The rather narrow band of just 15 supply risk points at the elemental level naturally limits the range, or spread, of results at the technology level, particularly since the aggregation algorithms are all some form of weighted average and the result will not lie outside the range between the lowest and the highest supply risk on the elemental level. This effect is actually stronger when more than one battery type contains the same element. (As noted above, the supply risk range at the elemental level in our previous study of PV materials was 25 points; the two technologies require different elements. The difference in supply risk score was 5 points: CdTe scored 57 points and CIGS 62 points using the simple arithmetic mean aggregation (Helbig et al., 2016).) Considering first the simple arithmetic mean, the supply risk scores for the six technologies are found to be 50 points for each of the four battery types LCO-C, LMO-C, NCA-C, NMC-C, 49 for LFP-C and 48 points for LFP-LTO (Figure 5). Using the uncertainty analysis (Figure 7), this allows us to conclude that there is - compared to the first five battery types - a statistically significant lower supply risk associated with the LFP-LTO battery. The range of supply risk values widens somewhat when the three elements lithium, carbon (graphite) and phosphorous are removed from the analysis (Figure 6). The values are then 51, 51, 51, 51, 49 and 46 points for LCO-C, LMO-C, NCA-C, NMC-C, LFP-C and LFP-LTO, respectively. Contrary to expectation, however, LFP-LTO remains the only technology for which a statistically significant lower supply risk exists compared to the other five technologies. This means that despite the lower score for LFP-C there is an overlap between its box in Figure 7 and those of the first four technologies because of the larger uncertainty. The mass-share aggregation method and the "maximum" approach give similar results. The cost share aggregation option with and without $\mathrm{Li}, \mathrm{C}$ and $\mathrm{P}$, gives, however, scores of 53, 49, 51, 52, 52 and 51 points; and 53, 49, 51, 51, 48 and 43 points, respectively, for the six battery types. In this case we conclude that here the reduction from ten to seven elements makes a measurable difference to the relative supply risks. There is a statistically significant higher supply risk associated with the LCO-C battery type compared to LMO-C, LFP-C and LFP-LTO using the reduced set of seven elements and the cost share aggregation approach. The differences associated with the removal of the three elements from the analysis are in general, however, not large.

Some comments on the methodology are probably also necessary at this point. Firstly, the present analysis has not been quite as successful at the technology level as originally hoped, partly because of the strong bunching of supply risk values at the elemental level, at least in comparison to our previous work on photovoltaic materials. Other factors notwithstanding we should emphasise that the rigid, but correct, application of the uncertainty analysis plays an important role in this result. The present results show several examples where differences in supply risk are established at the technology level, but these are not regarded as being statistically significant. More accurate and better compiled source data, as well as improvements in the methodology may, in the course of 
time, improve this situation. Secondly, for the three aggregation options arithmetic mean, massshare and cost-share, there is a compensatory effect in the supply risk assessment: Using more of a material with a low supply risk score or, alternatively, using other, different materials with a low supply risk score, lowers the supply risk estimated for the whole technology. This may be explained by realising that supply risk is also a measure of the likelihood of price rises. The first three aggregation options assess the additional effort that must be expended in order to counteract possible supply disruption. The amount of effort is clearly lower if the high-risk materials have a lower mass share, or lower cost share in the technology concerned. The cost-share approach is the most comprehensive of the three, as it contains the information also required for the arithmetic mean and mass-share approaches. Finally, the "maximum" approach involves a different perception of supply risk that focuses on the likelihood of a severe physical shortage, which is particularly an issue for materials with high market concentration risk. In the case of a severe physical shortage, supply has already (been) stopped and the battery cannot be manufactured. Increasing the complexity of a technology by adding another functional material then always leads to more possibilities for supply disruption and therefore to a supply risk that is at least as high as the supply risk of a technology containing fewer elements. Two concepts closely connected with supply risk cost increase and physical shortage - can thus be evaluated by cost-share aggregation and the maximum approach, respectively.

\section{Conclusions}

Using the scheme employed with some success for the materials in thin film photovoltaic devices (Helbig et al., 2016), we have evaluated in a comparative study the supply risks associated with lithium-ion battery materials.The lithium-ion technologies investigated are lithium cobalt oxide, lithium manganese oxide, nickel-manganese-cobalt, nickel-cobalt-aluminium, lithium iron phosphate and lithium iron phosphate with titanium oxide anode. In the first five cases the anodes consist of graphite. These battery types are normally designated LCO-C, LMO-C, NCA-C, NMC-C, LFP-C and LFPLTO, respectively, and contain the ten functional materials $\mathrm{Li}, \mathrm{Al}, \mathrm{Ti}, \mathrm{Fe}, \mathrm{Mn}, \mathrm{Co}, \mathrm{Ni}, \mathrm{Cu}, \mathrm{C}, \mathrm{P}$, whereby carbon actually refers to natural graphite. In the first stage of the analysis we apply the semiquantitative, comparative assessment scheme to evaluate the supply risks associated with the ten elements. Eleven different indicators in four supply risk categories, namely, "risk of supply reduction", "risk of demand increase", "concentration risk" and "political risk" are applied to each element; the weighting of the indicators is determined by external experts within the framework of an Analytic Hierarchy Process. The aggregation of the weighted, normalised indicator values gives a set of relative supply risk values on the elemental level on a scale of 0-100. Lithium and cobalt have the highest supply risk scores. Aluminium shows the lowest (39 points) followed by titanium (43 points). Copper, iron, nickel, graphite, manganese and phosphorous form the middle group. The range of supply risk scores is narrower than for the seven elements compared in our study of the materials for thin film photovoltaics. An uncertainty analysis has been used to compare supply risk values both at the elemental and technology levels.

In the second stage of the analysis we assess the six battery types, in order to determine the comparative supply risks at the technology level. For this purpose the elemental supply risk values are aggregated using four different methods, three of which are based on the (weighted) arithmetic mean. Due to the somewhat restrictive situation at the elemental level the supply risk values for all four methods also occur in narrow ranges. Using the uncertainty analysis for the "simple arithmetic mean" case, it is concluded that - compared to the other five battery types - the LFP-LTO battery has 
a statistically significant lower supply risk both with and without the three elements Li, Al and P (the latter are present in all batteries). The mass-share aggregation method gives similar results. For the cost share aggregation option, on the other hand, the reduction from ten to seven elements does cause a measurable difference in the relative supply risks. There is a statistically significant higher supply risk associated with the LCO-C battery type compared to LMO-C, LFP-C and LFP-LTO based on the reduced set of seven elements and only one aggregation method.

Further, we show that the differences in supply risk values caused by removing $\mathrm{Li}, \mathrm{Al}$ and $\mathrm{P}$ from the analysis are, in general, not large, which is again a consequence of the narrow band of values at the elemental level. All the battery types considered are also characterized by a similar level of supply risk. Switching to another battery technology does not help reduce these risks, with the exception of LFP-LTO which shows a statistically significant reduction in supply risk for the first three aggregation procedures compared to the other technologies. This result comes about, however, at the cost of reduced energy density.Concerning statistical significance, we note that the rigorous use of the uncertainty analysis in our assessment procedure sets stringent conditions for establishing differences in relative supply risk. The two other important results, namely, that the highest risk values are obtained for cobalt and lithium at the elemental level and for LCO-C at the technology level, do lead to a practical recommendation: It would be wise to continue, even intensify, research and development on Li-ion technologies in order to decrease the Li material intensity $(\mathrm{g} / \mathrm{Wh})$. Moreover, it is probably advisable to avoid using cobalt-containing batteries where possible. In addition, we also note the ethical question that has been posed in connection with the extraction and export of cobalt minerals from conflict regions. Measures such as Section 1502 Dodd-Frank Act and the corresponding EU legislation can obviously affect supply risk. This is already reflected in the political risk indicators, but the situation could rapidly worsen.

Future research can also address the issue of increasing the applicability of the assessment procedure to specific market conditions, e.g. if high market concentration leads to a high risk of severe physical shortages, or, if the technology price is highly dependent on the raw material price, to a stronger focus on price risks Finally, research on improvement of the quality of the source data and, possibly, on further development of the methodology is also required, in order to ease the restrictions imposed by the uncertainty analysis.

\section{Acknowledgements}

This work was supported by the Bavarian State Ministry of Education, Science and the Arts in the form of the graduate program "Resource strategy concepts for sustainable energy systems" at the Institute of Materials Resource Management (MRM) of the University of Augsburg, Germany. We particularly thank the colleagues who responded to the AHP questionnaire. We are also grateful to $\mathrm{H}$. Gasteiger und B. Reuter for very helpful discussions.

\section{Appendix A. Supplementary data}

Supplementary data associated with this article can be found, in the online version. 


\section{References}

Abraham, D.S., 2015. The Elements of Power: Gadgets, Guns, and the Struggle for a Sustainable Future in the Rare Metal Age. Yale University Press.

Achzet, B., Helbig, C., 2013. How to evaluate raw material supply risks - an overview. Resour. Policy 38, 435-447. doi:10.1016/j.resourpol.2013.06.003

Ali, S.H., Giurco, D., Arndt, N., Nickless, E., Brown, G., Demetriades, A., Durrheim, R., Enriquez, M.A., Kinnaird, J., Littleboy, A., Meinert, L.D., Oberhänsli, R., Salem, J., Schodde, R., Schneider, G., Vidal, O., Yakovleva, N., 2017. Mineral supply for sustainable development requires resource governance. Nature 543, 367-372. doi:10.1038/nature21359

Amnesty International, 2016. This is what we die for, human rights abuses in the democratic republic of the congo power the global trade in cobalt.

Andre, D., Kim, S.-J., Lamp, P., Lux, S.F., Maglia, F., Paschos, O., Stiaszny, B., 2015. Future generations of cathode materials: an automotive industry perspective. J. Mater. Chem. A 3, 6709-6732. doi:10.1039/C5TA00361J

Angerer, G., Marscheider-Weidemann, F., Lüllmann, A., Erdmann, L., Scharp, M., Handke, V., Marwede, M., 2009. Raw Materials for Emerging Technologies. Frauenhofer IRB Verlag, Stuttgart.

Arbabzadeh, M., Johnson, J.X., Keoleian, G. a, Rasmussen, P.G., Thompson, L.T., 2016. Twelve Principles for Green Energy Storage in Grid Applications. Environ. Sci. Technol. 50, 1046-55. doi:10.1021/acs.est.5b03867

Bauer, C., 2010. Ökobilanz von Lithium-Ionen Batterien.

Blomgren, G.E., 2017. The Development and Future of Lithium Ion Batteries. J. Electrochem. Soc. 164, A5019-A5025. doi:10.1149/2.0251701jes

Bradshaw, A.M., Reuter, B., Hamacher, T., 2013. The Potential Scarcity of Rare Elements for the Energiewende. Green 3, 93-111. doi:10.1515/green-2013-0014

Buchholz, P., Huy, D., Liedtke, M., Schmidt, M., 2015. DERA-Rohstoffliste 2014.

Ciacci, L., Reck, B.K., Nassar, N.T., Graedel, T.E., 2015. Lost by Design. Environ. Sci. Technol. 49, $9443-$ 9451. doi:10.1021/es505515z

Cunningham, L.M., 2014. Transparency in mineral extraction: the commodity story, the Dodd-Frank, and the emergence of "conflict-free." Western Washington University.

Delucchi, M.A., Yang, C., Burke, A.F., Ogden, J.M., Kurani, K., Kessler, J., Sperling, D., 2013. An assessment of electric vehicles: technology, infrastructure requirements, greenhouse-gas emissions, petroleum use, material use, lifetime cost, consumer acceptance and policy initiatives. Philos. Trans. R. Soc. A Math. Phys. Eng. Sci. 372, 20120325-20120325. doi:10.1098/rsta.2012.0325

DERA, 2016. DERA Preismonitor Dezember 2016.

Dewulf, J., Benini, L., Mancini, L., Sala, S., Blengini, G.A., Ardente, F., Recchioni, M., Maes, J., Pant, R., Pennington, D., 2015. Rethinking the Area of Protection "Natural Resources" in Life Cycle Assessment. Environ. Sci. Technol. 49, 5310-5317. doi:10.1021/acs.est.5b00734

Diekmann, J., Hanisch, C., Froböse, L., Schälicke, G., Loellhoeffel, T., Fölster, A.-S., Kwade, A., 2017. Ecological Recycling of Lithium-Ion Batteries from Electric Vehicles with Focus on Mechanical Processes. J. Electrochem. Soc. 164, A6184-A6191. doi:10.1149/2.0271701jes

Eisler, M.N., 2016. Cold War computers, California supercars, and the pursuit of lithium-ion power. Phys. Today 69, 30-36. doi:10.1063/PT.3.3296 
Ellingsen, L.A.-W., Majeau-Bettez, G., Singh, B., Srivastava, A.K., Valøen, L.O., Strømman, A.H., 2014. Life Cycle Assessment of a Lithium-Ion Battery Vehicle Pack. J. Ind. Ecol. 18, 113-124. doi:10.1111/jiec.12072

European Commission, 2016. A European Strategy for Low-Emission Mobility.

European Commission, 2014. Report on Critical Raw Materials for the EU: Report of the Ad hoc Working Group on defining critical raw materials. European Commission, Brussels, Belgium.

Eurostat, 2016a. Europe 2020 indicators - climate change and energy [WWW Document]. URL http://ec.europa.eu/eurostat/statistics-explained/index.php/Europe_2020_indicators__climate_change_and_energy (accessed 4.11.17).

Eurostat, 2016b. Renewable energy statistics [WWW Document]. URL http://ec.europa.eu/eurostat/ statistics-explained/index.php/Renewable_energy_statistics (accessed 4.11.17).

Frenzel, M., Kullik, J., Reuter, M.A., Gutzmer, J., 2017. Raw material "criticality" - sense or nonsense? J. Phys. D. Appl. Phys. 50, 123002. doi:10.1088/1361-6463/aa5b64

Gaines, L., Nelson, P., 2009. Lithium - Ion Batteries : Possible Materials Issues. Scenario 1-16.

Geth, F., Brijs, T., Kathan, J., Driesen, J., Belmans, R., 2015. An overview of large-scale stationary electricity storage plants in Europe: Current status and new developments. Renew. Sustain. Energy Rev. 52, 1212-1227. doi:10.1016/j.rser.2015.07.145

Ghadbeigi, L., Harada, J.K., Lettiere, B.R., Sparks, T.D., 2015. Performance and resource considerations of Li-ion battery electrode materials. Energy Environ. Sci. 8, 1640-1650. doi: 10.1039/C5EE00685F

Goe, M., Gaustad, G., 2014. Identifying critical materials for photovoltaics in the US: A multi-metric approach. Appl. Energy 123, 387-396. doi:10.1016/j.apenergy.2014.01.025

Goodenough, J.B., Park, K.S., 2013. The Li-ion rechargeable battery: A perspective. J. Am. Chem. Soc. 135, 1167-1176. doi:10.1021/ja3091438

Graedel, T.E., Harper, E.M., Nassar, N.T., Reck, B.K., 2015. On the materials basis of modern society. Proc. Natl. Acad. Sci. 112, 6295-6300. doi:10.1073/pnas.1312752110

Graedel, T.E., Reck, B.K., 2016. Six Years of Criticality Assessments: What Have We Learned So Far? J. Ind. Ecol. 20, 692-699. doi:10.1111/jiec.12305

Gröger, O., Gasteiger, H.A., Suchsland, J.-P., 2015. Review-Electromobility: Batteries or Fuel Cells? J. Electrochem. Soc. 162, A2605-A2622. doi:10.1149/2.0211514jes

Hammond, G.P., Hazeldine, T., 2015. Indicative energy technology assessment of advanced rechargeable batteries. Appl. Energy 138, 559-571. doi:10.1016/j.apenergy.2014.10.037

Helbig, C., Bradshaw, A.M., Kolotzek, C., Thorenz, A., Tuma, A., 2016. Supply risks associated with CdTe and CIGS thin-film photovoltaics. Appl. Energy 178, 422-433. doi:10.1016/ j.apenergy.2016.06.102

Hu, X., Zou, C., Zhang, C., Li, Y., 2017. Technological Developments in Batteries: A Survey of Principal Roles, Types, and Management Needs. IEEE Power Energy Mag. 15, 20-31. doi:10.1109/ MPE.2017.2708812

Hu, X., Zou, Y., Yang, Y., 2016. Greener plug-in hybrid electric vehicles incorporating renewable energy and rapid system optimization. Energy 111, 971-980. doi:10.1016/j.energy.2016.06.037

Jaguemont, J., Boulon, L., Dub??, Y., 2016. A comprehensive review of lithium-ion batteries used in hybrid and electric vehicles at cold temperatures. Appl. Energy 164, 99-114. doi:10.1016/ j.apenergy.2015.11.034 
Kim, T.-H.H., Park, J.-S.S., Chang, S.K., Choi, S., Ryu, J.H., Song, H.-K.K., 2012. The Current Move of Lithium Ion Batteries Towards the Next Phase. Adv. Energy Mater. 2, 860-872. doi:10.1002/ aenm.201200028

Li, Y., Bareño, J., Bettge, M., Abraham, D.P., Bareno, J., Bettge, M., Abraham, D.P., 2014. Unexpected Voltage Fade in LMR-NMC Oxides Cycled below the "Activation" Plateau. J. Electrochem. Soc. 162, A155-A161. doi:10.1149/2.0741501jes

Lu, Q., Wu, P.F., Shen, W.X., Wang, X.C., Zhang, B., Wang, C., 2016. Life Cycle Assessment of Electric Vehicle Power Battery. Mater. Sci. Forum 847, 403-410. doi:10.4028/www.scientific.net/ MSF.847.403

Majeau-Bettez, G., Hawkins, T.R., Strømman, A.H., 2011. Life Cycle Environmental Assessment of Lithium-Ion and Nickel Metal Hydride Batteries for Plug-In Hybrid and Battery Electric Vehicles. Environ. Sci. Technol. 45, 4548-4554. doi:10.1021/es103607c

Marina Martinez, C., Hu, X., Cao, D., Velenis, E., Gao, B., Wellers, M., 2016. Energy Management in Plug-in Hybrid Electric Vehicles: Recent Progress and a Connected Vehicles Perspective. IEEE Trans. Veh. Technol. PP, 1-1. doi:10.1109/TVT.2016.2582721

Marscheider-Weidemann, F., Langkau, S., Hummen, T., Erdmann, L., Tercero Espinoza, L., 2016. Rohstoffe für Zukunftstechnologien 2016, Deutsche Rohstoffagentur (DERA). doi:I D 4 - 020815 $-28 / 07$

Moss, R.L., Tzimas, E., Kara, H., Willis, P., Kooroshy, J., 2013. The potential risks from metals bottlenecks to the deployment of Strategic Energy Technologies. Energy Policy 55, 556-564. doi:10.1016/j.enpol.2012.12.053

Moss, R.L., Tzimas, E., Kara, H., Willis, P., Kooroshy, J., 2011. Critical Metals in Strategic Energy Technologies. European Commission, Luxembourg.

Nitta, N., Wu, F., Lee, J.T., Yushin, G., 2015. Li-ion battery materials: Present and future. Mater. Today 18, 252-264. doi:10.1016/j.mattod.2014.10.040

Notter, D.A., Gauch, M., Widmer, R., Wäger, P., Stamp, A., Zah, R., Althaus, H.-J., 2010. Contribution of Li-Ion Batteries to the Environmental Impact of Electric Vehicles. Environ. Sci. Technol. 44, 6550-6556. doi:10.1021/es903729a

Park, O.K., Cho, Y., Lee, S., Yoo, H.-C., Song, H.-K., Cho, J., 2011. Who will drive electric vehicles, olivine or spinel? Energy Environ. Sci. 4, 1621. doi:10.1039/c0ee00559b

Peters, J., Weil, M., 2016. A Critical Assessment of the Resource Depletion Potential of Current and Future Lithium-Ion Batteries. Resources 5, 46. doi:10.3390/resources5040046

Reuter, B., 2016a. Assessment of sustainability issues for the selection of materials and technologies during product design : a case study of lithium-ion batteries for electric vehicles. Int. J. Interact. Des. Manuf. doi:10.1007/s12008-016-0329-0

Reuter, B., 2016b. Bewertung von Nachhaltigkeitsaspekten zur Rohstoff- und Technologieauswahl für Elektrofahrzeuge.

Roelich, K., Dawson, D.A., Purnell, P., Knoeri, C., Revell, R., Busch, J., Steinberger, J.K., 2014. Assessing the dynamic material criticality of infrastructure transitions: A case of low carbon electricity. Appl. Energy 123, 378-386. doi:10.1016/j.apenergy.2014.01.052

Saaty, T.L., 2008. Decision making with the analytic hierarchy process. Int. J. Serv. Sci. 1, 83. doi:10.1504/IJSSCI.2008.017590 
Simon, B., Ziemann, S., Weil, M., 2015. Potential metal requirement of active materials in lithium-ion battery cells of electric vehicles and its impact on reserves: Focus on Europe. Resour. Conserv. Recycl. 104, 300-310. doi:10.1016/j.resconrec.2015.07.011

Sterner, M., Stadler, I., 2014. Energiespeicher - Bedarf, Technologien, Integration. Springer Vieweg, Berlin.

Tarascon, J.M., Armand, M., 2001. Issues and challenges facing rechargeable lithium batteries. Nature 414, 359-67. doi:10.1038/35104644

The Economist, 2017. The white gold rush. Econ.

Troy, S., Schreiber, A., Reppert, T., Gehrke, H.-G.G., Finsterbusch, M., Uhlenbruck, S., Stenzel, P., 2016. Life Cycle Assessment and resource analysis of all-solid-state batteries. Appl. Energy 169, 757-767. doi:10.1016/j.apenergy.2016.02.064

Tuma, A., Reller, A., Thorenz, A., Kolotzek, C., Helbig, C., 2014. Nachhaltige Ressourcenstrategien in Unternehmen: Identifikation kritischer Rohstoffe und Erarbeitung von Handlungsempfehlungen zur Umsetzung einer ressourceneffizienten Produktion. Universtität Augsburg, Deutsche Bundesstiftung Umwelt.

U.S. Department of Energy, 2011. Critical Materials Strategy. U.S. Department of Energy, Washington.

U.S. National Research Council, 2008. Minerals, Critical Minerals, and the U.S. Economy. The National Academies Press, Washington, DC.

United Nations/Framework Convention on Climate Change, 2015. Paris Agreement, 21st Conference of the Parties. doi:FCCC/CP/2015/L.9

USGS, 2016. Mineral Commodity Summaries 2016.

Vikström, H., Davidsson, S., Höök, M., 2013. Lithium availability and future production outlooks. Appl. Energy 110, 252-266. doi:10.1016/j.apenergy.2013.04.005

Wang, X., Gaustad, G., Babbitt, C.W., Bailey, C., Ganter, M.J., Landi, B.J., 2014. Economic and environmental characterization of an evolving Li-ion battery waste stream. J. Environ. Manage. 135, 126-134. doi:10.1016/j.jenvman.2014.01.021

Yoshino, A., 2012. The birth of the lithium-ion battery. Angew. Chemie - Int. Ed. 51, 5798-5800. doi:10.1002/anie.201105006

Yu, H., Zhou, H., 2013. High-Energy Cathode Materials (Li 2 MnO 3 -LiMO 2 ) for Lithium-Ion Batteries. J. Phys. Chem. Lett. 4, 1268-1280. doi:10.1021/jz400032v

Zackrisson, M., Avellán, L., Orlenius, J., 2010. Life cycle assessment of lithium-ion batteries for plug-in hybrid electric vehicles - Critical issues. J. Clean. Prod. 18, 1519-1529. doi:10.1016/j.jclepro. 2010.06.004

Zeng, X., Li, J., Singh, N., 2014. Recycling of spent lithium-ion battery: A critical review. Crit. Rev. Environ. Sci. Technol. 44, 1129-1165. doi:10.1080/10643389.2013.763578

Zepf, V., Simmons, J., Reller, A., Ashfield, M., Rennie, C., 2014. Materials critical to the energy industry. An Introduction., 2nd ed. BP p.I.c., London. 
Postprint

\title{
Supply risks associated with lithium-ion battery materials
}

\section{Appendix A. Supplementary data}

\author{
Christoph Helbig ${ }^{*}, \mathrm{a}$, Alex M. Bradshaw ${ }^{\mathrm{b}, \mathrm{c}}$, Lars Wietschel ${ }^{\mathrm{a}}$, Andrea Thorenz ${ }^{\mathrm{a}}$, Axel Tuma ${ }^{\mathrm{a}}$ \\ *Address correspondence to: christoph.helbig@wiwi.uni-augsburg.de \\ ${ }^{a}$ : Resource Lab, Institute of Materials Resource Management, University of Augsburg, \\ Universitaetsstr. 16, 86159 Augsburg, Germany \\ b: Max Planck Institute for Plasma Physics, Boltzmannstraße 2, 85748 Garching, Germany \\ c: Fritz Haber Institute, Faradayweg 4-6, 14195 Berlin, Germany
}

Supplementary Material to:

Supply risks associated with lithium-ion battery materials, Journal of Cleaner Production 172 (2018), available at https://doi.org/10.1016/i.jclepro.2017.10.122

\begin{tabular}{|c|c|c|c|}
\hline Section Topic & Tables & Figures & Page \\
\hline 1. Short explanation of the eleven indicators & $\mathrm{S} 1, \mathrm{~S} 2$ & & S2 \\
\hline 2. Supply risk information & S3 - S20 & & S4 \\
\hline 3. AHP questionnaire fore supply risk indicator weighting & & $\mathrm{S} 1-\mathrm{S} 3$ & S15 \\
\hline 4. Sensitivity analysis: alternative weightings & & S4-S6 & S18 \\
\hline 5. Monte Carlo simulation for uncertainty analysis & S21 & S7 & S19 \\
\hline 6.Comparison of the supply risk scores on the elemental level & S22 & & S21 \\
\hline
\end{tabular}




\section{Short explanation of the eleven indicators}

Table S4: Explanation of supply risk indicators for the criteria "risk of supply reduction" and "risk of demand increase".

The column "Calculation" describes - where appropriate - the normalization of the supply risk scores, or indicator values, to bring them onto a common linear scale of 0 to 100. The column "Sources" gives the references to the sources of the data used in calculating the indicator values. A short description of the origin and previous application of each indicator in resource studies, together with appropriate references, is given in Chapter 3 of the main text.

\begin{tabular}{|c|c|c|c|c|c|c|c|}
\hline & Indicator & Indicator Description & Unit & Min & Max & Calculation & Sources \\
\hline \multirow{3}{*}{ 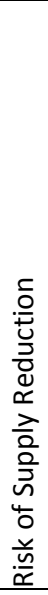 } & $\begin{array}{l}\text { Static Reach } \\
\text { Reserves }\end{array}$ & $\begin{array}{l}\text { The static reach of the reserves (SR) of a raw material is given by the ratio of annual primary } \\
\text { production to the estimated global reserves. Reserves are the ores currently technically and } \\
\text { economically extractable from known deposits. The figure is an indication of the market } \\
\text { pressure for further exploration and for the development of new extraction capabilities, } \\
\text { possibly leading to higher price levels. }\end{array}$ & years & 0 years & $\begin{array}{l}\text { infinite } \\
\text { ( } \infty \text { years) }\end{array}$ & $\begin{array}{l}S_{1}=100-0.2 \mathrm{SR}- \\
0.008 \mathrm{SR}^{2} \text { (Graedel et al., } \\
\text { 2012) }\end{array}$ & $\begin{array}{l}\text { (USGS, } \\
\text { 2015a) }\end{array}$ \\
\hline & $\begin{array}{l}\text { Static Reach } \\
\text { Resources }\end{array}$ & $\begin{array}{l}\text { The static reach of the resources (RR) of a raw material is measured by the ratio of annual } \\
\text { production to estimated global resources. Resources are deposits from which the economic } \\
\text { extraction of the ore is feasible, but not at present price levels. RR is the best available } \\
\text { measure of a possible physical scarcity of a raw material due to mineral depletion, } \\
\text { independent of current price levels. }\end{array}$ & years & 0 years & $\begin{array}{l}\text { infinite } \\
\text { ( } \infty \text { years) }\end{array}$ & $\begin{array}{l}S_{2}=100-0.1 \mathrm{RR}- \\
0.002 \mathrm{RR}^{2} \text { (Graedel et al., } \\
\text { 2012) }\end{array}$ & $\begin{array}{l}\text { (USGS, } \\
\text { 2015a) }\end{array}$ \\
\hline & $\begin{array}{l}\text { EoL-Recycling } \\
\text { Rate }\end{array}$ & $\begin{array}{l}\text { The end-of-life recycling rate (EoL-RR) of a raw material is given by the ratio of current } \\
\text { annual recycled material flow to the annual discard rate of the raw material. The value is an } \\
\text { estimate of the amount of available secondary material that is independent of mining and } \\
\text { primary refining activities and can thus smooth out supply disruptions or price peaks. }\end{array}$ & $\%$ & $0 \%$ & $100 \%$ & $S_{3}=100-$ EoL-RR & $\begin{array}{l}\text { (Graedel } \\
\text { et al., } \\
\text { 2011) }\end{array}$ \\
\hline \multirow{3}{*}{ 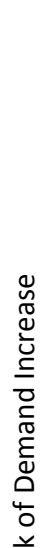 } & $\begin{array}{l}\text { By-Product } \\
\text { Dependence }\end{array}$ & $\begin{array}{l}\text { The by-product dependence (BPD) is the amount of an element mined as a by-product given } \\
\text { as a percentage of the global production of the host element(s). Extraction as a by-product } \\
\text { occurs when mining solely for the raw material itself is not economically feasible. The figure } \\
\text { is a measure of the possible inability to increase primary production in response to an } \\
\text { increase in demand. }\end{array}$ & $\%$ & $0 \%$ & $100 \%$ & $S_{4}=\mathrm{BPD}$ & $\begin{array}{l}\text { (Nassar } \\
\text { et al., } \\
2015 \text { ) }\end{array}$ \\
\hline & $\begin{array}{l}\text { Future } \\
\text { Technology } \\
\text { Demand }\end{array}$ & $\begin{array}{l}\text { Future technology demand (FTD) is given by the ratio of expected additional demand in a } \\
\text { future year from new, future technologies to the global production in a past year. The figure } \\
\text { gives an indication of the market pressure for an increase in global extraction due to future } \\
\text { technologies. }\end{array}$ & $\%$ & $0 \%$ & $\begin{array}{l}\text { infinite } \\
(\infty \%)\end{array}$ & $\begin{array}{l}S_{5}=((\sqrt[t]{(1+\mathrm{FTD})})-1) \\
\mathrm{t}=24 \text { years } \\
\text { (Schneider et al., 2014) }\end{array}$ & $\begin{array}{l}\text { (Angerer } \\
\text { et al., } \\
\text { 2009) }\end{array}$ \\
\hline & Substitutability & $\begin{array}{l}\text { Substitutability (Subst) is an estimate of the extent to which a raw material can be replaced } \\
\text { by another raw material, without there being a too great a loss of essential properties. It is } \\
\text { gauged by expert assessment. The value gives an estimates of the extent to which demand } \\
\text { can be shifted to other materials in the case of supply shortage and thus of the potential to }\end{array}$ & $\begin{array}{l}\text { dimensi } \\
\text { on-less }\end{array}$ & 0 & 100 & $S_{6}=100-$ Subst & $\begin{array}{l}\text { (Graedel } \\
\text { et al., } \\
\text { 2015) }\end{array}$ \\
\hline
\end{tabular}


Table S5: Explanation of supply risk indicators for the criteria "concentration risk" and "political risk".

The column "Calculation" describes - where appropriate - the normalization of the supply risk scores, or indicator values to bring them onto a common linear scale of 0 to 100. The column "Sources" gives the references to the sources of the data used in calculating the indicator values. A short description of the origin and previous application of each indicator in previous resource studies, together with appropriate references, is given in Chapter 3 of the main text.

\# Indicator Indicator Description

Country

The concentration of the annual production of a raw material in one, or in only a Concentration over the squares of the production shares of the countries in percent. The value indicates directly market concentration and thus the possibility of strategic exploitation of a monopolistic position at times of international crisis or dispute.

Company The concentration of the annual production of a raw material in the hands of one Concentration only a few, companies is measured by the Herfindahl-Hirschman Index, which is the sum over the squares of the production shares of the companies in percent. The value indicates directly market concentration and thus the occurrence of oligopolistic structures, which are linked in turn to higher price levels, low levels of competition and strategic misuse.

\begin{tabular}{|c|c|c|}
\hline \multirow{3}{*}{ 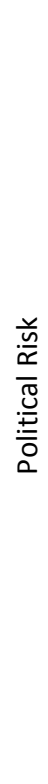 } & $\begin{array}{l}\text { Country Risk } \\
\text { Political } \\
\text { Stability }\end{array}$ & $\begin{array}{l}\text { The risk of political instability in producing countries is measured by the Worldwide } \\
\text { Governance Indicator for Political Stability and Absence of Violence/Terrorism, } \\
\text { published by the World Bank. It is weighted by the production share in each } \\
\text { producing country. The value is an indication of the likelihood of disruption in } \\
\text { production and export in the countries concerned due to unrest, coups d'état, } \\
\text { terrorism or other situations involving violence. }\end{array}$ \\
\hline & $\begin{array}{l}\text { Country Risk } \\
\text { Policy } \\
\text { Perception }\end{array}$ & $\begin{array}{l}\text { The indicator Policy Perception is an assessment of the ability of producing countries } \\
\text { to implement new mining projects, weighted by the production share in each } \\
\text { country. Policy Perception is evaluated by mining industry experts and summarized } \\
\text { by the Fraser Institute. The value is a measure of the ability of the market to } \\
\text { continue to function and/or of primary production to continue to increase based on } \\
\text { the functioning of the rule of law and governance procedures in producing countries. }\end{array}$ \\
\hline & $\begin{array}{l}\text { Country Risk } \\
\text { Regulation }\end{array}$ & $\begin{array}{l}\text { The "regulation risk" attempts to measure the likelihood of producing countries to } \\
\text { actually implement restrictions on mining, refining and trade, as indicated by their } \\
\text { level of societal development. This in turn is measured by the HDI (Human } \\
\text { Development Index), as presented by the United Nations Development Programme } \\
\text { and weighted by the production share in each producing country. The value assesses } \\
\text { the likelihood that further mineral extraction and refining activities are prevented }\end{array}$ \\
\hline
\end{tabular}

Unit

Herfindahl-

Min

Max

Calculation

Sources

Herfindahl-

Hirschman-Index

10000 et al., 2015)

\begin{tabular}{lllll}
$\begin{array}{l}\text { Worldwide } \\
\text { Governance } \\
\text { Indicator - Political }\end{array}$ & -2.5 & 2.5 & $S_{9}=20 *(2.5-$ WGI $)$ & $\begin{array}{l}\text { (Kaufmann } \\
\text { and Kraay, } \\
\text { 2015) }\end{array}$ \\
$\begin{array}{l}\text { Stability and } \\
\text { Absence of } \\
\text { Violence/Terrorism }\end{array}$ & & & & \\
$\begin{array}{l}\text { Policy Perception } \\
\text { Index }\end{array}$ & 0 & 100 & $S_{10}=100-$ PPI & $\begin{array}{l}\text { (Jackson } \\
\text { and } \\
\text { Green, } \\
\text { 2015) }\end{array}$ \\
& & & & \\
& & & & \\
\hline $\begin{array}{l}\text { Human } \\
\text { Development }\end{array}$ & 0 & 1 & $S_{11}=100 *$ HDI & (UNDP, \\
Index & & & $2014)$
\end{tabular}




\section{Supply risk information}

In order to calculate the normalised supply risk scores, or indicator values, for all eleven indicators raw data from many sources are required. Tables S3 - S18 give the essential data and provide additional relevant information where appropriate. Table S3 brings together data on reserves, resources and production rates for the nine elements (lithium, aluminium, titanium, manganese, iron, cobalt, nickel, copper and phosphorous), from which the static reach figures in Table S4 are calculated. Tables S4 - S7 give the elemental data for all four categories "risk of supply reduction", "risk of demand increase", "concentration risk" and "political risk", respectively. Four of the supply risk indicators ("country concentration", "political stability", policy perception" and "regulation risk") rely on data from the various producing countries. Tables S8 - S17 therefore display the countryspecific data used in the assessment of the nine elements. Table S18 comprises the main result of the analysis and shows the normalized supply risk scores on a scale $0-100$ for all nine elements and all eleven indicators. It corresponds to Figure $X$ in the main paper. Finally, Table S19 gives information on the prices of the nine elements (in 2016), so that an aggregation for the elements in each type of battery can also be performed in a way that takes into account the price of the element ("cost share" basis).

Table S6: Reserves, resources and production rates for the nine elements.

\begin{tabular}{|c|c|c|c|c|c|c|c|c|c|c|}
\hline Indicator & $\mathrm{Li}$ & $\mathrm{Al}$ & $\mathrm{TiO}_{2}$ & $\mathrm{Mn}$ & Fe ore & Co & $\mathrm{Ni}$ & $\mathrm{Cu}$ & Graphite & $\mathrm{PO}_{4}$ \\
\hline Reserves $^{2}$ & $14000 \mathrm{kt}$ & $28000 \mathrm{Mt}$ & $790 \mathrm{Mt}$ & $620 \mathrm{Mt}$ & $85 \mathrm{Gt}$ & $7100 \mathrm{kt}$ & $79 \mathrm{Mt}$ & $720 \mathrm{Mt}$ & $230 \mathrm{Mt}$ & $69 \mathrm{Gt}$ \\
\hline Resources $^{2}$ & $40700 \mathrm{kt}$ & $55000 \mathrm{Mt}$ & $2000 \mathrm{Mt}$ & Large & $230 \mathrm{Gt}$ & $145 \mathrm{Mt}$ & $130 \mathrm{Mt}$ & $5600 \mathrm{Mt}$ & $800 \mathrm{Mt}$ & $290 \mathrm{Gt}$ \\
\hline Production ${ }^{2}$ & $32.5 \mathrm{kt}$ & $274 \mathrm{Mt}$ & $6090 \mathrm{kt}$ & $18 \mathrm{Mt}$ & $3320 \mathrm{Mt}$ & $124 \mathrm{kt}$ & $2530 \mathrm{kt}$ & $18500 \mathrm{kt}$ & $1190 \mathrm{kt}$ & $223 \mathrm{Mt}$ \\
\hline $\begin{array}{l}\text { Production } \\
\text { type }^{3}\end{array}$ & mining & mining & mining & mining & mining & mining & mining & mining & mining & mining \\
\hline $\begin{array}{l}\text { Main host } \\
\text { metal }^{4}\end{array}$ & K & - & - & - & - & $\mathrm{Ni}, \mathrm{Cu}$ & - & - & & - \\
\hline
\end{tabular}

Table S7: Elemental data for the risk of supply reduction. $\bigoplus$ : Higher figures indicate high risk. $\ominus$ : Lower figures indicate high risk.

\begin{tabular}{|c|c|c|c|c|c|c|c|c|c|c|c|c|}
\hline Indicator & Dimension & Risk & $\mathrm{Li}$ & Al & $\mathrm{Ti}$ & $\mathrm{Mn}$ & $\mathrm{Fe}$ & Co & $\mathrm{Ni}$ & $\mathrm{Cu}$ & C & $P$ \\
\hline $\begin{array}{l}\text { Static } \\
\text { Reach } \\
\text { Reserves }^{5}\end{array}$ & years & $\ominus$ & $431 \mathrm{a}$ & $102 \mathrm{a}$ & $130 \mathrm{a}$ & $34 a$ & $26 a$ & $57 a$ & $31 a$ & $39 a$ & $193 \mathrm{a}$ & $309 a$ \\
\hline $\begin{array}{l}\text { Static } \\
\text { Reach } \\
\text { Resources }^{6}\end{array}$ & years & $\ominus$ & $1250 \mathrm{a}$ & $201 \mathrm{a}$ & $328 a$ & long time & $69 a$ & 1170 a & $51 \mathrm{a}$ & $303 a$ & $672 \mathrm{a}$ & $1300 \mathrm{a}$ \\
\hline $\begin{array}{l}\text { End-of-Life } \\
\text { Recycling } \\
\text { Rate }^{7}\end{array}$ & $\%$ & $\theta$ & $1 \%$ & $60 \%$ & $1 \%$ & $53 \%$ & $67 \%$ & $68 \%$ & $58 \%$ & $53 \%$ & $0 \%$ & $1 \%$ \\
\hline
\end{tabular}

\footnotetext{
${ }^{2}$ (USGS, 2016), values for 2015

3 (USGS, 2016)

${ }^{4}$ (Rankin, 2011)

${ }^{5}$ calculated from reserves and production

${ }^{6}$ calculated from resources and production

7 (European Commission, 2014; Graedel et al., 2011)
} 
Table S8: Elemental data for the risk of demand increase. $\bigoplus$ : Higher figures indicate higher risk. $\ominus$ : Lower figures indicate higher risk.

\begin{tabular}{lllllllllllll} 
Indicator & Dimension & Risk & $\mathrm{Li}$ & $\mathrm{Al}$ & $\mathrm{Ti}$ & $\mathrm{Mn}$ & $\mathrm{Fe}$ & $\mathrm{Co}$ & $\mathrm{Ni}$ & $\mathrm{Cu}$ & $\mathrm{C}$ & $\mathrm{P}$ \\
\hline By-product Dependence $^{8}$ & $\%$ & $\oplus$ & $52 \%$ & $0 \%$ & $0 \%$ & $3 \%$ & $<1 \%$ & $85 \%$ & $2 \%$ & $9 \%$ & 0 & $0 \%$ \\
\hline Future Technology Demand $^{9}$ & $\%$ & $\oplus$ & $390 \%$ & n/av & n/av & n/av & n/av & $90 \%$ & n/av & n/av & 0 & n/av \\
\hline Substitutability $^{10}$ & qualitative & $\ominus$ & 59 & 56 & 37 & 4 & 43 & 46 & 38 & 30 & 28 & 3
\end{tabular}

Table S9: Elemental data for concentration risk. $\bigoplus$ : Higher figures indicate higher risk. $\ominus$ : Lower figures indicate higher risk.

\begin{tabular}{|c|c|c|c|c|c|c|c|c|c|c|c|c|}
\hline Indicator & Dimension & Risk & $\mathrm{Li}$ & Al & $\mathrm{Ti}$ & $\mathrm{Mn}$ & $\mathrm{Fe}$ & Co & $\mathrm{Ni}$ & $\mathrm{Cu}$ & C & $P$ \\
\hline $\begin{array}{l}\text { Country } \\
\text { Concentration } \\
(\mathrm{HHI})^{11}\end{array}$ & $\mathrm{HHI}$ & $\oplus$ & 3195 & $3244^{12}$ & 862 & 1818 & 2562 & 2808 & 1126 & 1666 & 4579 & 2563 \\
\hline $\begin{array}{l}\text { Company } \\
\text { Concentration } \\
(\mathrm{HHI})^{13}\end{array}$ & $\mathrm{HHI}$ & $\oplus$ & 1664 & $2221^{14}$ & 1317 & 1357 & 837 & $1902^{15}$ & 1191 & 1108 & 4760 & 2239 \\
\hline
\end{tabular}

Table S10: Elemental data for political risk. $\bigoplus$ : Higher figures indicate higher risk. $\ominus$ : Lower figures indicate higher risk.

\begin{tabular}{lllllllllllll} 
Indicator & Dimension & Risk & $\mathrm{Li}$ & $\mathrm{Al}$ & $\mathrm{Ti}$ & $\mathrm{Mn}$ & $\mathrm{Fe}$ & $\mathrm{Co}$ & $\mathrm{Ni}$ & $\mathrm{Cu}$ & $\mathrm{C}$ & $\mathrm{P}$ \\
\hline $\begin{array}{l}\text { Political Stability } \\
\text { (WGI-PV) }^{16}\end{array}$ & qualitative & $\oplus$ & 0.59 & -0.17 & -0.07 & -0.01 & -0.01 & -1.13 & -0.10 & 0.03 & -0.50 & -0.36 \\
\hline Policy Perception (PPI) $^{17}$ & qualitative & $\oplus$ & 79 & 60 & 57 & 57 & 61 & 51 & 56 & 66 & 49 & 55 \\
\hline Regulation Risk (HDI) $^{18}$ & qualitative & $\ominus$ & 0.86 & 0.77 & 0.71 & 0.73 & 0.79 & 0.59 & 0.75 & 0.77 & 0.72 & 0.74
\end{tabular}

Table S11: Country-specific lithium data.

\begin{tabular}{lllll} 
Country (Region) & $\begin{array}{l}\text { 2015 Production, } \mathrm{t} \\
\text { (Geoscience Australia, } \\
\text { 2013; USGS, 2016) }\end{array}$ & $\begin{array}{l}\text { WGI-PV 2014 (Kaufmann } \\
\text { and Kraay, 2015) }\end{array}$ & $\begin{array}{l}\text { PPI 2015 (Jackson and } \\
\text { Green, 2016) }\end{array}$ & $\begin{array}{l}\text { HDI 2014 } \\
\text { (UNDP, 2015) }\end{array}$ \\
\hline United States & $\mathrm{n} / \mathrm{av}^{19}$ & 0.62 & - & 0.92 \\
\hline $\begin{array}{l}\text { Argentina } \\
\text { (Catamarca) }\end{array}$ & $1267^{20}$ & 0.08 & 44 & 0.84 \\
\hline Argentina (Jujuy) & $1267^{20}$ & 0.08 & 43 & 0.84
\end{tabular}

\footnotetext{
${ }^{8}$ (Nassar et al., 2015; Vesborg and Jaramillo, 2012)

${ }^{9}$ (Marscheider-Weidemann et al., 2016), value is only the additional demand from future technologies

${ }^{10}$ (European Commission, 2014; Graedel et al., 2015), values rescaled so that 100 is "fully substitutable" and 0 is "no substitute available"

11 calculated from country-specific data of (USGS, 2016), values for 2015

${ }^{12}$ value for aluminum; alumina (2853) and bauxite (1688) have lower levels of concentration

${ }^{13}$ (Buchholz et al., 2015)

${ }^{14}$ value for aluminum ; alumina (2198) and bauxite (771) have lower levels of concentration

${ }^{15}$ value for refining; mining (449) has lower level of concentration

${ }^{16}$ calculated from (USGS, 2016) and (Kaufmann and Kraay, 2015)

${ }^{17}$ calculated from (USGS, 2016) and (Jackson and Green, 2016)

${ }^{18}$ calculated from (USGS, 2016) and (UNDP, 2015)

${ }^{19} \mathrm{n} / \mathrm{av}$ : not available, data from USA withheld by USGS

${ }^{20}$ total production for Argentina was $3800 \mathrm{t}$, production was assumed to only happen in the three provinces Catamarca, Jujuy and Salta,

but no distribution was available, therefore equal distribution was assumed
} 


\begin{tabular}{lllll} 
Argentina (Salta) & $1267^{20}$ & 0.08 & 62 & 0.84 \\
\hline $\begin{array}{l}\text { Australia (Western } \\
\text { Australia) }\end{array}$ & 13400 & 1.08 & 92 & 0.94 \\
\hline Brazil & 160 & -0.01 & 57 & 0.76 \\
\hline Chile & 11700 & 0.49 & 83 & 0.83 \\
\hline China & 2200 & -0.46 & 46 & 0.73 \\
\hline Portugal & 300 & 0.79 & 90 & 0.83 \\
\hline Zimbabwe & 900 & -0.65 & 25 & 0.51
\end{tabular}

Table S12: Country-specific aluminium/alumina/bauxite data.

\begin{tabular}{|c|c|c|c|c|c|c|}
\hline Country (Region) & $\begin{array}{l}2015 \\
\text { Aluminum } \\
\text { Production, } \\
\text { kt } \\
\text { (USGS, 2016) }\end{array}$ & $\begin{array}{l}2015 \\
\text { Alumina } \\
\text { Production, } \\
\text { kt } \\
\text { (USGS, 2016) }\end{array}$ & $\begin{array}{l}2015 \text { Bauxite } \\
\text { Production, } \\
\text { kt } \\
\text { (USGS, 2016) }\end{array}$ & $\begin{array}{l}\text { WGI-PV } 2014 \\
\text { (Kaufmann } \\
\text { and Kraay, } \\
\text { 2015) }\end{array}$ & $\begin{array}{l}\text { PPI } 2015 \\
\text { (Jackson } \\
\text { and Green, } \\
2016 \text { ) }\end{array}$ & $\begin{array}{l}\text { HDI } 2014 \\
\text { (UNDP, } \\
2015)\end{array}$ \\
\hline United States & 1600 & 4000 & $\mathrm{n} / \mathrm{av}^{21}$ & 0.62 & - & 0.92 \\
\hline Australia (total) & 1650 & 20200 & & 1.08 & - & 0.94 \\
\hline Australia (Western Australia) & & & $26700^{22}$ & 1.08 & 92 & 0.94 \\
\hline Australia (Northern Territory) & & & $26700^{22}$ & 1.08 & 85 & 0.94 \\
\hline Australia (Queensland) & & & $26700^{22}$ & 1.08 & 79 & 0.94 \\
\hline Bahrain & 960 & & & -0.94 & $50^{23}$ & 0.82 \\
\hline Brazil & 780 & 10300 & 35000 & -0.01 & 57 & 0.76 \\
\hline Canada & 2900 & & & 1.18 & - & 0.91 \\
\hline China & 32000 & 57000 & 60000 & -0.46 & 46 & 0.73 \\
\hline Greece & & 800 & 1900 & 0.02 & 39 & 0.87 \\
\hline Guinea & & & 17700 & -0.93 & 36 & 0.41 \\
\hline Guyana & & & 1700 & -0.16 & 60 & 0.64 \\
\hline Iceland & 850 & & & 1.24 & $50^{23}$ & 0.72 \\
\hline India & 2350 & 5470 & 19200 & -0.96 & 48 & 0.61 \\
\hline Indonesia & & 300 & 1000 & -0.37 & 40 & 0.68 \\
\hline Jamaica & & 1950 & 10700 & 0.09 & $50^{23}$ & 0.72 \\
\hline Kazakhstan & & 1600 & 5200 & 0.05 & 70 & 0.79 \\
\hline Malaysia & & & 21200 & 0.34 & 61 & 0.78 \\
\hline Norway & 1320 & & & 1.13 & 89 & 0.94 \\
\hline Qatar & 640 & & & 1.00 & $50^{23}$ & 0.85 \\
\hline Russia & 3500 & 2580 & 6600 & -0.84 & 52 & 0.80 \\
\hline Saudi Arabia & 740 & & & -0.24 & $50^{23}$ & 0.84 \\
\hline
\end{tabular}




\begin{tabular}{|c|c|c|c|c|c|c|}
\hline South Africa & 690 & & & -0.08 & 52 & 0.67 \\
\hline Suriname & & 970 & 2200 & 0.23 & $50^{23}$ & 0.71 \\
\hline United Arab Emirates & 2340 & & & 0.81 & $50^{23}$ & 0.84 \\
\hline Venezuela & & 650 & 1500 & -0.83 & 0 & 0.76 \\
\hline Vietnam & & 500 & 1100 & 0.00 & 35 & 0.67 \\
\hline Other $^{24}$ & 6010 & 11400 & 8500 & 0 & 50 & 0.71 \\
\hline
\end{tabular}

Table S13: Country-specific titanium dioxide data.

\begin{tabular}{|c|c|c|c|c|c|}
\hline Country (Region) & $\begin{array}{l}2015 \text { Production Ilmenite } \\
\text { (TiO2 content), kt } \\
\text { (Geoscience Australia, } \\
\text { 2013; Natural Resources } \\
\text { Canada, 2015; USGS, 2016) }\end{array}$ & $\begin{array}{l}2015 \text { Production } \\
\text { Rutile (TiO2 } \\
\text { concent), kt } \\
\text { (Geoscience } \\
\text { Australia, 2013; } \\
\text { USGS, 2016) }\end{array}$ & $\begin{array}{l}\text { WGI-PV } 2014 \\
\text { (Kaufmann and } \\
\text { Kraay, 2015) }\end{array}$ & $\begin{array}{l}\text { PPI } 2015 \\
\text { (Jackson and } \\
\text { Green, 2016) }\end{array}$ & $\begin{array}{l}\text { HDI } 2014 \\
\text { (UNDP, } \\
2015 \text { ) }\end{array}$ \\
\hline $\begin{array}{l}\text { United States } \\
\text { (Florida) }\end{array}$ & $33^{25}$ & 0 & 0.62 & $50^{26}$ & 0.92 \\
\hline $\begin{array}{l}\text { United States } \\
\text { (Georgia) }\end{array}$ & $33^{25}$ & 0 & 0.62 & $50^{26}$ & 0.92 \\
\hline $\begin{array}{l}\text { United States } \\
\text { (Virginia) }\end{array}$ & $33^{25}$ & 0 & 0.62 & $50^{26}$ & 0.92 \\
\hline $\begin{array}{l}\text { Australia (South } \\
\text { Australia) }\end{array}$ & $180^{25}$ & $36^{25}$ & 1.08 & 86 & 0.94 \\
\hline $\begin{array}{l}\text { Australia } \\
\text { (Western } \\
\text { Australia) }\end{array}$ & $180^{25}$ & $36^{25}$ & 1.08 & 92 & 0.94 \\
\hline $\begin{array}{l}\text { Australia } \\
\text { (Northern } \\
\text { Territory) } \\
\end{array}$ & $180^{25}$ & $36^{25}$ & 1.08 & 85 & 0.94 \\
\hline $\begin{array}{l}\text { Australia } \\
\text { (Queensland) }\end{array}$ & $180^{25}$ & $36^{25}$ & 1.08 & 79 & 0.94 \\
\hline Brazil & 100 & 0 & -0.01 & 57 & 0.76 \\
\hline Canada (Quebec) & 360 & 0 & 1.18 & 85 & 0.91 \\
\hline China & 900 & 0 & -0.46 & 46 & 0.73 \\
\hline India & 210 & 18 & -0.96 & 48 & 0.61 \\
\hline Kenya & 430 & 65 & -1.27 & 46 & 0.55 \\
\hline Madagascar & 240 & 9 & -0.54 & 52 & 0.51 \\
\hline Mozambique & 450 & 0 & -0.35 & 52 & 0.42 \\
\hline Norway & 420 & 0 & 1.13 & 89 & 0.94 \\
\hline Russia & 100 & 0 & -0.84 & 52 & 0.80 \\
\hline Senegal & 230 & 0 & -0.13 & $50^{26}$ & 0.47 \\
\hline Sierra Leone & 0 & 110 & -0.22 & $50^{26}$ & 0.41 \\
\hline South Africa & 480 & 55 & -0.08 & 52 & 0.67 \\
\hline
\end{tabular}

\footnotetext{
${ }^{24}$ for "other" countries, the mean value was assumed for all country-specific indicators (WGI-PV 0, PPI 50, HDI 0.711)

${ }^{25}$ only states with mining activities could be identified, therefore equal distribution was assumed

${ }^{26}$ some countries do not have a Policy Perception Index, in which case the mean PPI of 50 was assumed
} 


\begin{tabular}{llllll} 
Ukraine & 240 & 63 & -1.93 & $50^{26}$ & 0.75 \\
\hline Vietnam & 540 & 0 & 0.00 & 35 & 0.67 \\
\hline Other $^{27}$ & 90 & 19 & 0 & 50 & 0.71
\end{tabular}

Table S14: Country-specific manganese data.

\begin{tabular}{lllll} 
Country (Region) & $\begin{array}{l}\text { 2015 Production, kt } \\
\text { (Geoscience Australia, } \\
2013 ; \text { USGS, 2016) }\end{array}$ & $\begin{array}{l}\text { WGI-PV 2014 (Kaufmann } \\
\text { and Kraay, 2015) }\end{array}$ & $\begin{array}{l}\text { PPI 2015 (Jackson and } \\
\text { Green, 2016) }\end{array}$ & $\begin{array}{l}\text { HDI 2014 } \\
\text { (UNDP, 2015) }\end{array}$ \\
\hline $\begin{array}{l}\text { Australia (Northern } \\
\text { Territory) }\end{array}$ & 2900 & 1.08 & 85 & 0.94 \\
\hline Brazil & 1000 & -0.01 & 57 & 0.76 \\
\hline Myanmar & 100 & -1.06 & 17 & 0.73 \\
\hline China & 3000 & -0.46 & 46 & 0.68 \\
\hline Gabon & 1800 & 0.20 & $50^{26}$ & 0.58 \\
\hline Ghana & 390 & -0.13 & 69 & 0.61 \\
\hline India & 950 & -0.96 & 48 & 0.79 \\
\hline Kazakhstan & 390 & 0.05 & 70 & 0.78 \\
\hline Malaysia & 400 & 0.34 & 61 & 0.76 \\
\hline Mexico & 240 & -0.76 & 71 & 0.67 \\
\hline South Africa & 6200 & -0.08 & 52 & 0.75 \\
\hline Ukraine & 390 & -1.93 & 50 & 0.71 \\
\hline Other ${ }^{27}$ & 740 & 0 & 50 & 26 \\
\hline
\end{tabular}

Table S15: Country-specific iron ore data.

\begin{tabular}{|c|c|c|c|c|}
\hline Country (Region) & $\begin{array}{l}2015 \text { Production, Mt } \\
\text { (Geoscience Australia, 2013; } \\
\text { Natural Resources Canada, 2015; } \\
\text { USGS, 2016) }\end{array}$ & $\begin{array}{l}\text { WGI-PV } 2014 \\
\text { (Kaufmann and Kraay, } \\
\text { 2015) }\end{array}$ & $\begin{array}{l}\text { PPI } 2015 \text { (Jackson } \\
\text { and Green, 2016) }\end{array}$ & $\begin{array}{l}\text { HDI } 2014 \\
\text { (UNDP, } \\
\text { 2015) }\end{array}$ \\
\hline $\begin{array}{l}\text { United States } \\
\text { (Michigan) }\end{array}$ & $22^{28}$ & 0.62 & 88 & 0.92 \\
\hline $\begin{array}{l}\text { United States } \\
\text { (Minnesota) }\end{array}$ & $22^{28}$ & 0.62 & 82 & 0.92 \\
\hline $\begin{array}{l}\text { Australia (South } \\
\text { Australia) }\end{array}$ & 9 & 1.08 & 86 & 0.94 \\
\hline $\begin{array}{l}\text { Australia (Northern } \\
\text { Territory) }\end{array}$ & 812 & 1.08 & 85 & 0.94 \\
\hline Brazil & 428 & -0.01 & 57 & 0.76 \\
\hline $\begin{array}{l}\text { Canada (Newfoundland } \\
\text { and Labrador) }\end{array}$ & 17 & 1.18 & 88 & 0.91 \\
\hline Canada (Quebec) & 22 & 1.18 & 85 & 0.91 \\
\hline China & 1380 & -0.46 & 46 & 0.73 \\
\hline
\end{tabular}

\footnotetext{
${ }^{27}$ for "other" countries, the mean value was assumed for all country-specific indicators (WGI-PV 0, PPI 50, HDI 0.711)

${ }^{28}$ only states with mining activities could be identified, therefore equal distribution was assumed
} 


\begin{tabular}{|c|c|c|c|c|}
\hline India & 129 & -0.96 & 48 & 0.61 \\
\hline Iran & 33 & -0.91 & $50^{29}$ & 0.77 \\
\hline Kazakhstan & 25 & 0.05 & 70 & 0.79 \\
\hline Russia & 112 & -0.84 & 52 & 0.80 \\
\hline South Africa & 80 & -0.08 & 52 & 0.67 \\
\hline Sweden & 37 & 1.07 & 96 & 0.91 \\
\hline Ukraine & 68 & -1.93 & $50^{29}$ & 0.75 \\
\hline Other ${ }^{30}$ & 125 & 0 & 50 & 0.71 \\
\hline
\end{tabular}

Table S16: Country-specific cobalt data.

\begin{tabular}{|c|c|c|c|c|}
\hline Country (Region) & $\begin{array}{l}2015 \text { Production, t } \\
\text { (Geoscience Australia, 2013; } \\
\text { Natural Resources Canada, 2015; } \\
\text { USGS, 2016) }\end{array}$ & $\begin{array}{l}\text { WGI-PV } 2014 \\
\text { (Kaufmann and Kraay, } \\
\text { 2015) }\end{array}$ & $\begin{array}{l}\text { PPI } 2015 \text { (Jackson } \\
\text { and Green, 2016) }\end{array}$ & $\begin{array}{l}\text { HDI } 2014 \\
\text { (UNDP, } \\
2015 \text { ) }\end{array}$ \\
\hline $\begin{array}{l}\text { United States } \\
\text { (Michigan) }\end{array}$ & 700 & 0.62 & 88 & 0.92 \\
\hline $\begin{array}{l}\text { Australia (Western } \\
\text { Australia) }\end{array}$ & 6000 & 1.08 & 92 & 0.94 \\
\hline Brazil & 2600 & -0.01 & 57 & 0.76 \\
\hline $\begin{array}{l}\text { Canada (Newfoundland } \\
\text { and Labrador) }\end{array}$ & 1980 & 1.18 & 88 & 0.91 \\
\hline Canada (Quebec) & 1620 & 1.18 & 85 & 0.91 \\
\hline Canada (Ontario) & 2300 & 1.18 & 79 & 0.91 \\
\hline Canada (Manitoba) & 400 & 1.18 & 89 & 0.91 \\
\hline China & 7200 & -0.46 & 46 & 0.73 \\
\hline Congo, Dem. Rep. & 63000 & -2.27 & 43 & 0.43 \\
\hline Cuba & 4200 & 0.60 & $50^{29}$ & 0.77 \\
\hline Madagaskar & 3600 & -0.54 & 52 & 0.51 \\
\hline New Caledonia ${ }^{31}$ & 3300 & 0 & 60 & 0.71 \\
\hline Philippines & 4600 & 0.70 & 41 & 0.67 \\
\hline Russia & 6300 & -0.84 & 52 & 0.80 \\
\hline South Africa & 2800 & -0.08 & 52 & 0.67 \\
\hline Zambia & 5500 & 0.21 & 63 & 0.59 \\
\hline Other $^{30}$ & 7700 & 0 & 50 & 0.71 \\
\hline
\end{tabular}

${ }^{29}$ some countries do not have a Policy Perception Index, in which case the mean PPI of 50 was assumed

${ }^{30}$ for "other" countries, the mean value was assumed for all country-specific indicators (WGI-PV 0, PPI 50, HDI 0.711)

${ }^{31}$ New Caledonia does not have a WGI-PV score nor an HDI score, therefore mean values (WGI-PV 0 and HDI 0.711 ) were assumed 
Table S17: Country-specific nickel data.

\begin{tabular}{|c|c|c|c|c|}
\hline Country (Region) & $\begin{array}{l}2015 \text { Production, t } \\
\text { (Geoscience Australia, 2013; } \\
\text { Natural Resources Canada, 2015; } \\
\text { USGS, 2016) }\end{array}$ & $\begin{array}{l}\text { WGI-PV } 2014 \\
\text { (Kaufmann and Kraay, } \\
\text { 2015) }\end{array}$ & $\begin{array}{l}\text { PPI } 2015 \text { (Jackson } \\
\text { and Green, 2016) }\end{array}$ & $\begin{array}{l}\text { HDI } 2014 \\
\text { (UNDP, } \\
2015 \text { ) }\end{array}$ \\
\hline $\begin{array}{l}\text { United States } \\
\text { (Michigan) }\end{array}$ & 26500 & 0.62 & 88 & 0.92 \\
\hline $\begin{array}{l}\text { Australia (Western } \\
\text { Australia) }\end{array}$ & 234000 & 1.08 & 92 & 0.94 \\
\hline Brazil & 110000 & -0.01 & 57 & 0.76 \\
\hline $\begin{array}{l}\text { Canada (Newfoundland } \\
\text { and Labrador) }\end{array}$ & 53600 & 1.18 & 88 & 0.91 \\
\hline Canada (Quebec) & 56800 & 1.18 & 85 & 0.91 \\
\hline Canada (Ontario) & 103000 & 1.18 & 79 & 0.91 \\
\hline Canada (Manitoba) & 26500 & 1.18 & 89 & 0.91 \\
\hline China & 102000 & -0.46 & 46 & 0.73 \\
\hline Colombia & 73000 & -1.12 & 54 & 0.72 \\
\hline Cuba & 57000 & 0.60 & $50^{32}$ & 0.77 \\
\hline Guatemala & 50000 & -0.64 & 46 & 0.63 \\
\hline Indonesia & 170000 & -0.37 & 40 & 0.68 \\
\hline Madagascar & 49000 & -0.54 & 52 & 0.51 \\
\hline New Caledonia ${ }^{33}$ & 190000 & 0 & 60 & 0.71 \\
\hline Philippines & 530000 & 0.70 & 41 & 0.67 \\
\hline Russia & 240000 & -0.84 & 52 & 0.80 \\
\hline South Africa & 53000 & -0.08 & 52 & 0.67 \\
\hline Other ${ }^{34}$ & 410000 & 0 & 50 & 0.71 \\
\hline
\end{tabular}

Table S18: Country-specific copper data.

\begin{tabular}{lllll} 
Country (Region) & $\begin{array}{l}\text { 2015 Production, kt } \\
\text { (Geoscience Australia, 2013; } \\
\text { Natural Resources Canada, 2015; } \\
\text { USGS, 2016, 2015b) }\end{array}$ & $\begin{array}{l}\text { WGI-PV 2014 } \\
\text { (Kaufmann and } \\
\text { Kraay, 2015) }\end{array}$ & $\begin{array}{l}\text { PPI 2015 (Jackson } \\
\text { and Green, 2016) }\end{array}$ & $\begin{array}{l}\text { HDI 2014 } \\
\text { (UNDP, } \\
2015)\end{array}$ \\
\hline $\begin{array}{l}\text { United States (Arizona) } \\
\text { United States (other) }\end{array}$ & 795 & 0.62 & 88 & 0.92 \\
\hline $\begin{array}{l}\text { Australia (South } \\
\text { Australia) }\end{array}$ & 285 & 0.62 & $50^{32}$ & 0.92 \\
\hline $\begin{array}{l}\text { Australia (New South } \\
\text { Wales) }\end{array}$ & 163 & 1.08 & 86 & 0.94 \\
\hline Australia (Tasmania) & 28 & 1.08 & 69 & 0.94 \\
\hline Australia (Western & 191 & 1.08 & 78 & 0.94
\end{tabular}

Australia)

\footnotetext{
${ }^{32}$ some countries do not have a Policy Perception Index, in which case the mean PPI of 50 was assumed

${ }^{33}$ New Caledonia does not have a WGI-PV score nor an HDI score, therefore mean values (WGI-PV 0 and HDI 0.711) were assumed

${ }^{34}$ for "other" countries, the mean value was assumed for all country-specific indicators (WGI-PV 0, PPI 50, HDI 0.711)
} 


\begin{tabular}{|c|c|c|c|c|}
\hline Australia (Queensland) & 247 & 1.08 & 79 & 0.94 \\
\hline $\begin{array}{l}\text { Canada } \\
\text { (Newfoundland and } \\
\text { Labrador) }\end{array}$ & 44 & 1.18 & 88 & 0.91 \\
\hline Canada (Quebec) & 46 & 1.18 & 85 & 0.91 \\
\hline Canada (Ontario) & 195 & 1.18 & 79 & 0.91 \\
\hline Canada (Manitoba) & 40 & 1.18 & 89 & 0.91 \\
\hline $\begin{array}{l}\text { Canada } \\
\text { (Saskatchewan) }\end{array}$ & 1 & 1.18 & 95 & 0.91 \\
\hline $\begin{array}{l}\text { Canada (British } \\
\text { Columbia) }\end{array}$ & 342 & 1.18 & 75 & 0.91 \\
\hline Canada (Yukon) & 16 & 1.18 & 77 & 0.91 \\
\hline Chile & 5700 & 0.49 & 83 & 0.73 \\
\hline China & 1750 & -0.46 & 46 & 0.73 \\
\hline Congo, Dem. Rep. & 990 & -2.27 & 43 & 0.43 \\
\hline Mexico & 550 & -0.76 & 71 & 0.76 \\
\hline Peru & 1600 & -0.53 & 67 & 0.73 \\
\hline Russia & 740 & -0.84 & 52 & 0.80 \\
\hline Zambia & 600 & 0.21 & 63 & 0.59 \\
\hline Other $^{34}$ & 3900 & 0 & 50 & 0.71 \\
\hline
\end{tabular}


Table S19: Country-specific graphite data.

\begin{tabular}{|c|c|c|c|c|}
\hline Country (Region) & $\begin{array}{l}2015 \text { Production, kt } \\
\text { (Natural Resources Canada, } \\
\text { 2015; USGS, 2016) }\end{array}$ & $\begin{array}{l}\text { WGI-PV } 2014 \text { (Kaufmann } \\
\text { and Kraay, 2015) }\end{array}$ & $\begin{array}{l}\text { PPI } 2015 \text { (Jackson and } \\
\text { Green, 2016) }\end{array}$ & $\begin{array}{l}\text { HDI } 2014 \\
\text { (UNDP, 2015) }\end{array}$ \\
\hline Brazil & 80 & -0.01 & 57 & 0.76 \\
\hline Canada (Quebec) & $15^{35}$ & 1.18 & 85 & 0.91 \\
\hline $\begin{array}{l}\text { Canada (British } \\
\text { Columbia) }\end{array}$ & $15^{35}$ & 1.18 & 75 & 0.91 \\
\hline China & 780 & -0.46 & 46 & 0.73 \\
\hline India & 170 & -0.96 & 48 & 0.61 \\
\hline Korea, North & 30 & -1.09 & $50^{36}$ & $0.71^{37}$ \\
\hline Madagascar & 5 & -0.54 & 52 & 0.51 \\
\hline Mexico & 22 & -0.76 & 71 & 0.76 \\
\hline Norway & 8 & 1.13 & 89 & 0.94 \\
\hline Russia & 15 & -0.84 & 52 & 0.80 \\
\hline Sri Lanka & 4 & -0.25 & $50^{36}$ & 0.76 \\
\hline Turkey & 32 & -1.06 & 71 & 0.76 \\
\hline Ukraine & 5 & -1.93 & $50^{36}$ & 0.75 \\
\hline Zimbabwe & 7 & -0.65 & 25 & 0.51 \\
\hline Other $^{38}$ & 1 & 0 & 50 & 0.71 \\
\hline
\end{tabular}

Table S20: Country-specific phosphate ore data.

\begin{tabular}{lllll} 
Country (Region) & $\begin{array}{l}\text { 2015 Production } \\
\text { phosphate rock, kt } \\
\text { (Geoscience Australia, } \\
2013 ; \text { USGS, 2016) }\end{array}$ & $\begin{array}{l}\text { WGI-PV 2014 (Kaufmann } \\
\text { and Kraay, 2015) }\end{array}$ & $\begin{array}{l}\text { PPI 2015 (Jackson } \\
\text { and Green, 2016) }\end{array}$ & $\begin{array}{l}\text { HDI 2014 } \\
\text { (UNDP, 2015) }\end{array}$ \\
\hline $\begin{array}{l}\text { United States } \\
\text { (Florida) }\end{array}$ & $11040^{39}$ & 0.62 & $50^{36}$ & 0.92 \\
\hline $\begin{array}{l}\text { United States (Idaho) } \\
2760^{39}\end{array}$ & 0.62 & 86 & 0.92 \\
\hline $\begin{array}{l}\text { United States (North } \\
\text { Carolina) }\end{array}$ & $11040^{39}$ & 0.62 & $50^{36}$ & 0.92 \\
\hline United States (Utah) & $2760^{39}$ & 0.62 & 89 & 0.92 \\
\hline Algeria & 1200 & -1.17 & $50^{36}$ & 0.94 \\
\hline $\begin{array}{l}\text { Australia } \\
\text { (Queensland) }\end{array}$ & 2600 & 1.08 & 79 & 0.73 \\
\hline China & 100000 & -0.46 & 46 & 0.69 \\
\hline Egypt & 5500 & -1.58 & $50^{36}$ & 0.61
\end{tabular}

\footnotetext{
${ }^{35}$ only states with mining activities could be identified, therefore equal distribution was assumed

${ }^{36}$ some countries do not have a Policy Perception Index, in which case the mean PPI of 50 was assumed

${ }^{37}$ North Korea is not listed in the HDI report, therefore global average of 0.711 was assumed

${ }^{38}$ for "other" countries, the mean value was assumed for all country-specific indicators (WGI-PV 0, PPI 50, HDI 0.711)

${ }^{39}$ Florida and North Carolina make up $80 \%$ of US production, Idaho and Utah the remaining $20 \%$
} 


\begin{tabular}{lllll} 
Iraq & 200 & -2.47 & $50^{36}$ & 0.65 \\
\hline Israel & 3300 & -0.99 & $50^{36}$ & 0.77 \\
\hline Jordan & 7500 & -0.56 & 51 & 0.75 \\
\hline Kazakhstan & 1600 & 0.05 & $50^{36}$ & 0.79 \\
\hline Mexico & 1700 & -0.76 & 71 & 0.76 \\
\hline $\begin{array}{l}\text { Morocco and West } \\
\text { Sahara }\end{array}$ & 30000 & -0.39 & 84 & 0.63 \\
\hline Peru & 4000 & -0.53 & 67 & 0.73 \\
\hline Russia & 12500 & -0.84 & 52 & 0.80 \\
\hline Saudi Arabia & 3300 & -0.24 & $50^{36}$ & 0.84 \\
\hline Senegal & 1000 & -0.13 & $50^{36}$ & 0.47 \\
\hline South Africa & 2200 & -0.08 & 52 & 0.67 \\
\hline Syria & 750 & -2.76 & $50^{36}$ & 0.59 \\
\hline Togo & 1000 & -0.16 & $50^{36}$ & 0.48 \\
\hline Tunisia & 4000 & -0.93 & $50^{36}$ & 0.72 \\
\hline Vietnam & 2700 & 0.00 & 35 & 0.67 \\
\hline Other ${ }^{38}$ & 2600 & 0 & 50 & 0.71
\end{tabular}

Table S21: Normalized elemental supply risk scores for all eleven indicators. Higher figures indicate higher risk.

\begin{tabular}{lcccccccccc} 
Indicator & $\mathrm{Li}$ & $\mathrm{Al}$ & $\mathrm{Ti}$ & $\mathrm{Mn}$ & $\mathrm{Fe}$ & $\mathrm{Co}$ & $\mathrm{Ni}$ & $\mathrm{Cu}$ & $\mathrm{C}$ & $\mathrm{P}$ \\
\hline Static Reach Reserves & 0 & 0 & 0 & 84 & 90 & 62 & 86 & 80 & 0 & 0 \\
\hline Static Reach Resources & 0 & 0 & 0 & 0 & 55 & 0 & 74 & 0 & 0 & 0 \\
\hline EoL-Recycling Rate & 99 & 40 & 99 & 47 & 33 & 32 & 42 & 47 & 100 & 100 \\
\hline By-Product Dependence & 52 & 0 & 0 & 3 & 1 & 85 & 2 & 9 & 0 & 0 \\
\hline Future Technology Demand & 75 & 0 & 0 & 0 & 0 & 30 & 0 & 0 & 0 & 0 \\
\hline Substitutability & 41 & 44 & 63 & 96 & 57 & 46 & 62 & 70 & 72 & 98 \\
\hline Country Concentration & 75 & 76 & 47 & 63 & 71 & 73 & 53 & 61 & 83 & 71 \\
\hline Company Concentration & 72 & 76 & 68 & 68 & 61 & 74 & 66 & 65 & 88 & 76 \\
\hline Political Stability & 38 & 53 & 51 & 50 & 50 & 73 & 52 & 49 & 60 & 57 \\
\hline Policy Perception & 21 & 40 & 43 & 43 & 39 & 49 & 44 & 34 & 51 & 45
\end{tabular}

Table S22: Relative mass contribution of the ten elements.

\begin{tabular}{lllllll} 
Element & $\begin{array}{l}\text { LCO-C (Lu et } \\
\text { al., 2016) }\end{array}$ & $\begin{array}{l}\text { LMO-C (Peters } \\
\text { and Weil, 2016) }\end{array}$ & $\begin{array}{l}\text { NCA-C (Peters } \\
\text { and Weil, 2016) }\end{array}$ & $\begin{array}{l}\text { NMC-C (Peters } \\
\text { and Weil, 2016) }\end{array}$ & $\begin{array}{l}\text { LFP-C (Peters } \\
\text { and Weil, 2016) }\end{array}$ & $\begin{array}{l}\text { LFP-LTO (Peters } \\
\text { and Weil, 2016) }\end{array}$ \\
\hline $\mathrm{Li}$ & $2.82 \%$ & $1.32 \%$ & $3.55 \%$ & $3.94 \%$ & $3.18 \%$ & $6.47 \%$ \\
\hline $\mathrm{Al}$ & $31.42 \%$ & $18.67 \%$ & $12.50 \%$ & $6.98 \%$ & $10.87 \%$ & $28.94 \%$ \\
\hline $\mathrm{Ti}$ & $0.00 \%$ & $0.00 \%$ & $0.00 \%$ & $0.00 \%$ & $0.00 \%$ & $31.57 \%$
\end{tabular}




\begin{tabular}{lllllll}
$\mathrm{Mn}$ & $0.00 \%$ & $18.83 \%$ & $0.00 \%$ & $10.11 \%$ & $0.00 \%$ & $0.00 \%$ \\
\hline $\mathrm{Fe}$ & $0.00 \%$ & $0.00 \%$ & $0.00 \%$ & $0.00 \%$ & $24.19 \%$ & $20.49 \%$ \\
\hline $\mathrm{Co}$ & $22.70 \%$ & $0.00 \%$ & $4.33 \%$ & $10.84 \%$ & $0.00 \%$ & $0.00 \%$ \\
\hline $\mathrm{Ni}$ & $0.00 \%$ & $0.00 \%$ & $23.03 \%$ & $10.80 \%$ & $0.00 \%$ & $0.00 \%$ \\
\hline $\mathrm{Cu}$ & $18.85 \%$ & $30.79 \%$ & $24.10 \%$ & $32.90 \%$ & $24.87 \%$ & $0.00 \%$ \\
\hline $\mathrm{C}$ & $23.56 \%$ & $29.79 \%$ & $31.84 \%$ & $23.92 \%$ & $22.70 \%$ & $0.00 \%$ \\
\hline $\mathrm{P}$ & $0.65 \%$ & $0.59 \%$ & $0.65 \%$ & $0.51 \%$ & $14.19 \%$ & $12.52 \%$
\end{tabular}

Table S23: Metal price information.

Metal Reference commodity (DERA, 2016)

Price of commodity,

Price pure metal, USD $/ \mathrm{kg}$

January to December 2016, calculated from commodity price

\begin{tabular}{|c|c|c|c|}
\hline & & USD/kg (DERA, 2016) & \\
\hline Li & $\begin{array}{l}\text { Lithium-Carbonate, min. 99-99.5 \% Li2CO3, } \\
\text { large contracts, USA, delivered continental }\end{array}$ & 7.46 USD/kg & 39.70 USD/kg \\
\hline Al & $\begin{array}{l}\text { London metal exchange (LME), high grade } \\
\text { primary, cash, in LME warehouse }\end{array}$ & 1.60 USD/kg & 1.56 USD/kg \\
\hline $\mathrm{Ti}$ & $\begin{array}{l}\text { Rutile concentrate, min. } 95 \% \mathrm{TiO} 2 \text {, bagged, } \\
\text { Australia, fob }\end{array}$ & 0.71 USD/kg & 1.24 USD/kg \\
\hline $\mathrm{Mn}$ & $\begin{array}{l}99.7 \% \text { electrolytic manganese flakes, MB free } \\
\text { market, in warehouse }\end{array}$ & 1.86 USD/kg & 1.86 USD/kg \\
\hline $\mathrm{Fe}$ & MB Iron ore index (62\%), cfr main China port & 0.06 USD/kg & 0.09 USD/kg \\
\hline Co & $\begin{array}{l}\text { High grade, min. } 99.8 \% \text {, MB free market, in } \\
\text { warehouse }\end{array}$ & 26.43 USD/kg & $26.48 \mathrm{USD} / \mathrm{kg}$ \\
\hline $\mathrm{Ni}$ & $\begin{array}{l}\mathrm{LME} \text {, primary, } \min .99 .8 \% \text {, cash, in LME } \\
\text { warehouse }\end{array}$ & 9.59 USD/kg & 9.61 USD/kg \\
\hline $\mathrm{Cu}$ & LME, grade $A$, cash, in LME warehouse & 4.86 USD/kg & 4.86 USD/kg \\
\hline $\mathrm{C}$ & $\begin{array}{l}\text { Crystalline large flake, } 94-97 \% \text { C, }+80 \text { mesh, } \\
\text { cif main European port }\end{array}$ & 0.86 USD/kg & 0.86 USD/kg \\
\hline$P$ & Marocco, 70 \% bpl, contract, fas Casablanca & 0.11 USD/kg & 0.80 USD/kg \\
\hline
\end{tabular}




\section{AHP questionnaire for supply risk indicator weighting by external experts}

The following Analytic Hierarchy Process questionnaire was filled out by ten international experts in order to determine the weighting of the eleven supply risk indicators. Most of them are from academia, due to a lower response rate from industry experts. The academic institutions are universities and other governmental research institutions. Industry experts represent nongovernmental research institutions belonging to environmental consulting agencies. Six experts are from Germany, two from Japan and one each from Canada and the United Kingdom.

Expert questionnaire to evaluate the supply risks of raw materials for lithium-ion battery technologies

The goal of this questionnaire

Using an appropriate evaluation model we are planning to assess the relative supply risks associated with different lithium-ion battery technologies. The aim of the questionnaire is to put this exercise on a broader basis by involving experts in the field.

Four risk categories are considered: (1) risk of supply reduction, (2) risk of demand increase, (3) risk of concentration in a few hands and (4) political risk. Each category consists of two or three indicators, making eleven in total. The weighting of each indicator is not pre-determined. Your valuable help will contribute to this part of the assessment. A brief explanation of the indicators can be found on pages 4 and 5 .

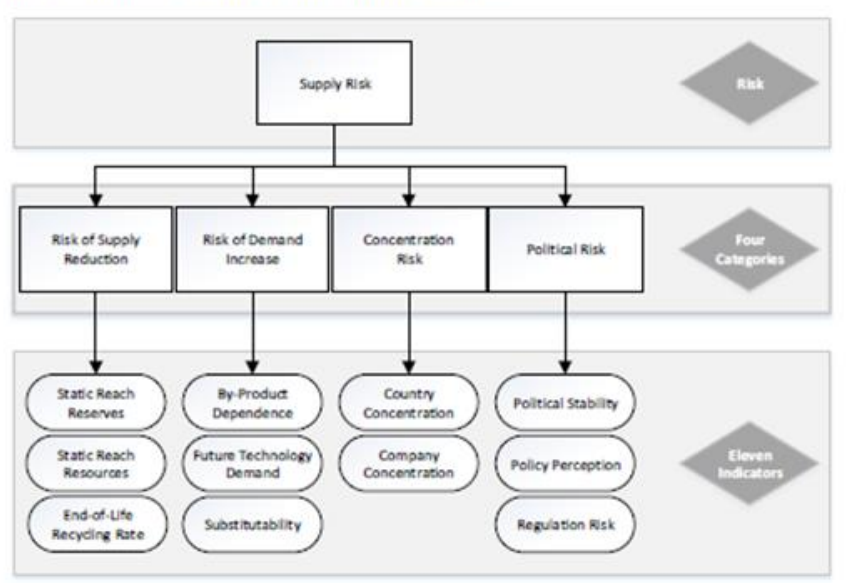

Figure 1: Evaluation model showing the eleven supply risk indicators in four categories

You have two tasks in this questionnaire: Your first task is the pairwise comparison of the overall importance of the four supply risk categories (see table 1 on page 2). This will determine the weighting of the categories.

Your second task is the pairwise comparison of the importance of the indicators within each of the four categories (see tables 2 to 5 on page 2). These comparisons determine the local weighting of the indicators within each category. We will then calculate the global weighting of the eleven supply risk indicators. Please note that we would like to have your opinion concerning the general importance of these supply risk aspects in the context of lithiumion battery technologies; we are not asking whether or not the supply risk aspects are already an issue for these materials.

An example of the procedure for the pairwise comparison of three indicators, which also serves for the pairwise comparison of categories, can be seen on page 3 . On pages 4 and 5 , you can find a short explanation of the indicators and their interpretation for raw material supply risks.

For both tasks in the questionnaire, an evaluation scale from 1 to 9 is used for the pairwise comparisons:

- 1 (both indicators/categories are equally important)

9 (one indicator/category is extremely dominant)

Page 1 of 5

Figure S8: AHP Questionnaire, part 1 
Expert questionnaire to evaluate the supply risks of raw materials for lithium-ion battery technologies Please use the following rating scale:

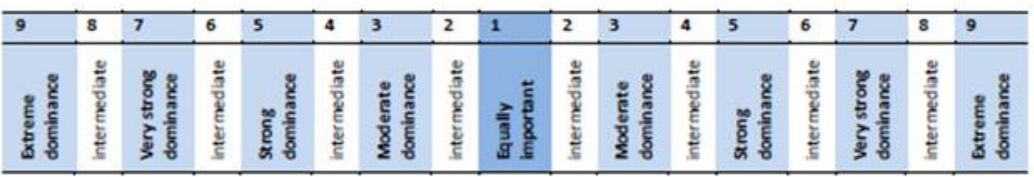

Questionnaire task 1: Deciding the weighting of each category

Please fill in your individual evaluation of the categories here.

Please make sure to fill each line with a cross for the evaluation, but only use a single cross for each line.

Table 1: Pairwise comparison of the four categories overall

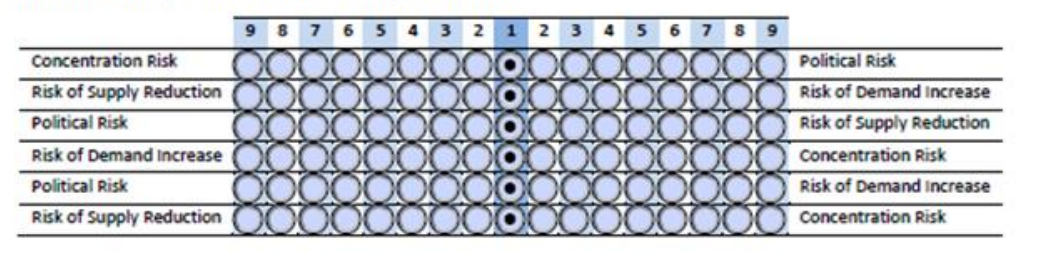

Questionnaire task 2: Deciding the weighting of each indicator

Table 2: Pairwise comparison of the three indicators in the category Risk of Supply Reduction

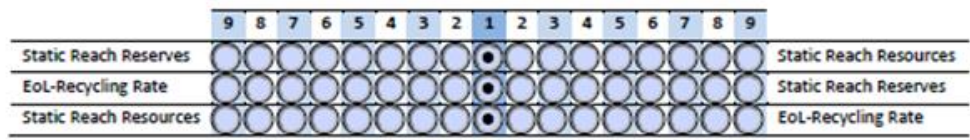

Table 3: Pairwise comparison of the three indicators in the category Risk of Demand Increase

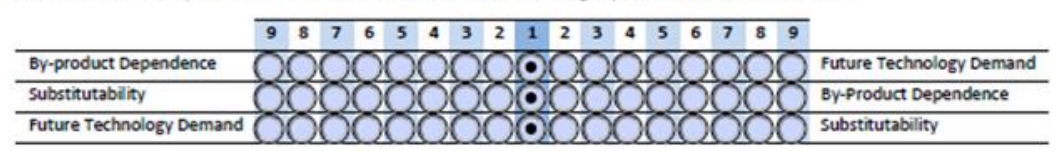

Table 4: Pairwise comparison of the two indicators in the category Concentration Risk

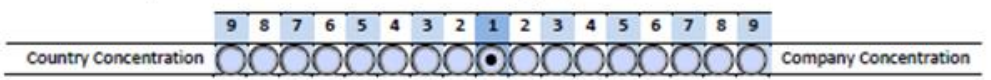

Table 5: Pairwise comparison of the three indicators in the category Political Risk

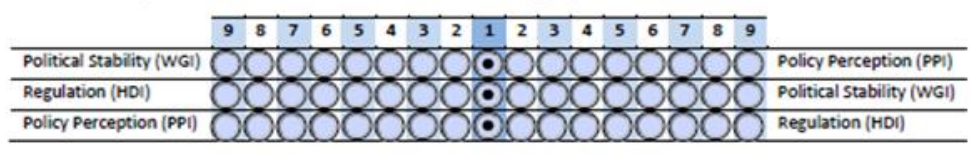

Many thanks for your time and for putting your expertise at our disposal! Page 2 of 5

Figure S9: AHP Questionnaire, part 2 
Expert questionnaire to evaluate the supply risks of raw materials for lithium-ion battery technologies Example for the pairwise comparison of the importance of indicators

Please use the following rating scale:

\begin{tabular}{|c|c|c|c|c|c|c|c|c|c|c|c|c|c|c|c|c|}
\hline 9 & 8 & 7 & 6 & 5 & 4 & 3 & 2 & 1 & 2 & 3 & 4 & 5 & 6 & 7 & 8 & 9 \\
\hline 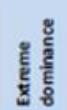 & 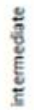 & 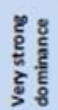 & 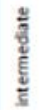 & हूँ & $\begin{array}{l}\text { हूँ } \\
\text { है } \\
\text { है }\end{array}$ & 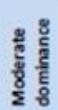 & 를 & 츨 & 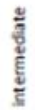 & 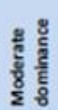 & 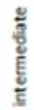 & है है है है & 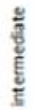 & 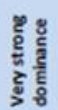 & 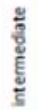 & हूँ \\
\hline
\end{tabular}

In order to make a pairwise comparison of three indicators ( $\mathrm{A}, \mathrm{B}$ and $\mathrm{C}$ ) three comparisons are required:

$1^{\text {tt }}$ comparison:

$2^{\text {ne }}$ comparison:

the relative importance of indicators $A$ and $B$, using the above rating scale

$3^{\text {ro }}$ comparison: the relative importance of indicators $C$ and $A$, using the above rating scale the relative importance of indicators $B$ and $C$, using the above rating scale

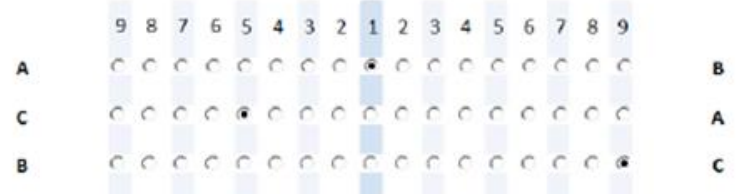

Figure 2: Example for the painwise comparison of three indicators A, B and C

In the first pairwise comparison, the two indicators $A$ and $B$ are judged to be equally important (value 1 on the scale), i.e. indicators $A$ and $B$ are weighted with a ratio of 1 to 1 .

In the second pairwise comparison, the indicator $\mathrm{C}$ is assessed to have a strong dominance over indicator $\mathrm{A}$ (value 5 on the scale on the side of indicator $\mathrm{C}$ ), i.e. the indicators $\mathrm{C}$ and $\mathrm{A}$ are weighted with a ratio of 5 to 1.

In the third pairwise comparison, the indicator $\mathrm{C}$ is assessed to have an extreme dominance over indicator $\mathrm{B}$ (value 9 on the scale on the side of indicator $\mathrm{C}$ ), i.e. the indicators $\mathrm{C}$ and $\mathrm{B}$ are weighted with a ratio of 9 to 1.

Combining the three pairwise comparisons via a mathematical evaluation, the resulting relative weighting of the three indicators is:

$A: B: C=12.7 \%: 10.4 \%: 76.9 \%$

Page 3 of 5

Figure S10: AHP Questionnaire, part 3

Pages 4 and 5 of the questionnaire are identical with pages $\$ 2$ and $S 3$ of this Supplementary Material. 


\section{Sensitivity analysis: alternative weightings}

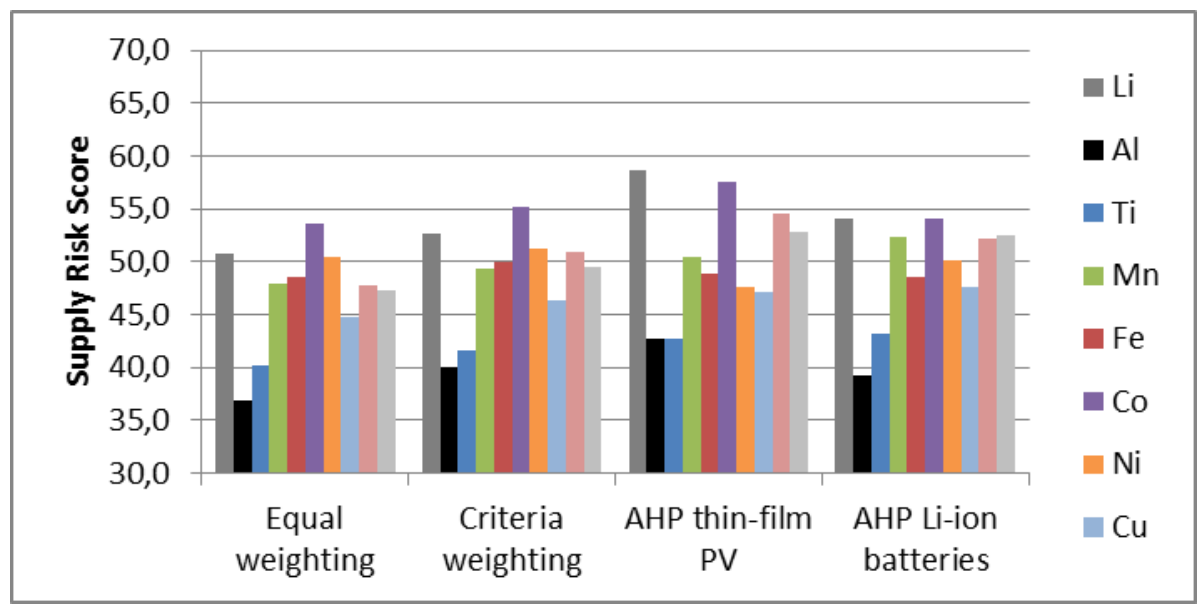

Figure S11: Supply Risk Score on the elemental level. Equal weighting: All indicators same weighting. Criteria weighting: All risk categories same weighting. AHP thin-film PV: Weightings based on AHP including 10 experts selected for thin-film PV. AHP Li-ion batteries: Weightings based on AHP including 10 experts selected for Li-lon battery technologies.

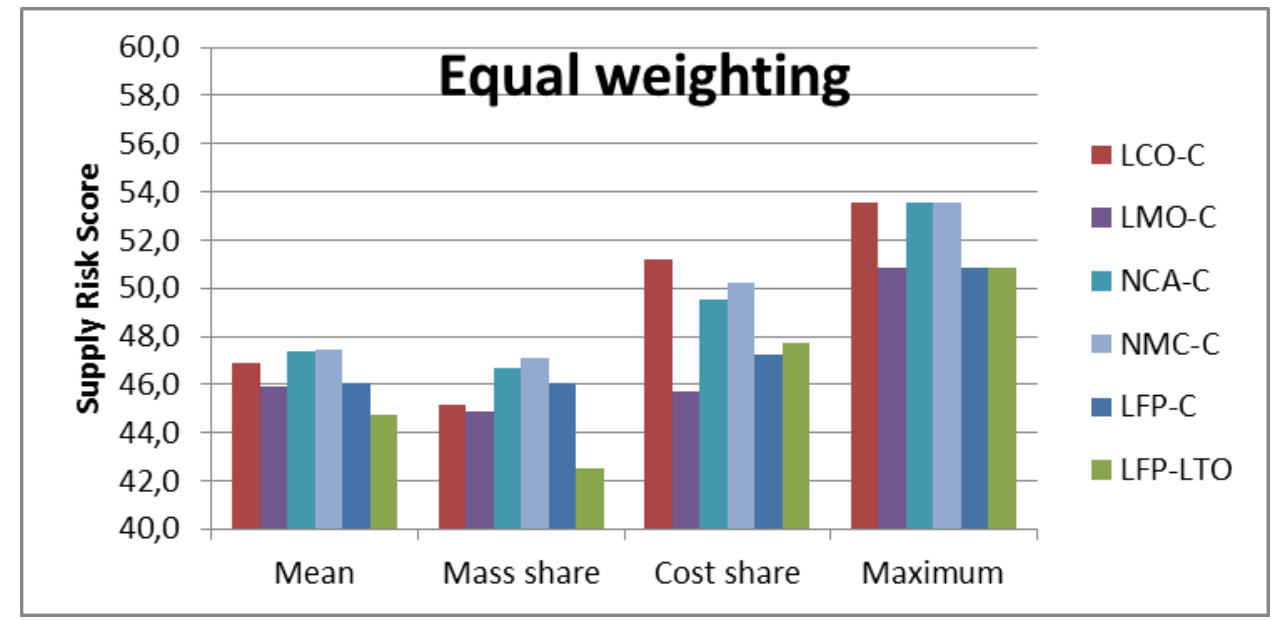

Figure S12: Results on the technology level for equal weighting of each indicator.

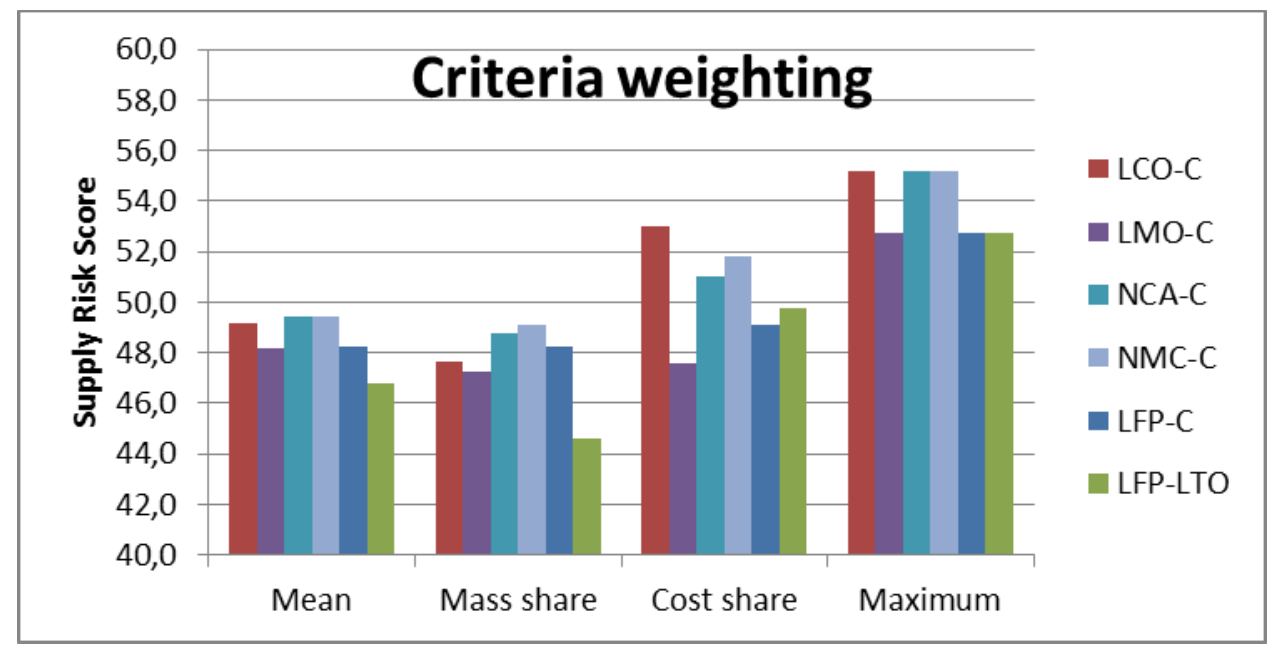

Figure S13: Results on the technology level for criteria weighting of each indicator. 


\section{Uncertainty analysis}

In order to test the results of our assessment with respect to data gaps and uncertainties, we have performed a Monte Carlo simulation. Raw data were given an assumed distribution (lognormal, normal, triangular or equal) and 10000 sequences with software-generated random numbers according to these distributions were used to calculate resulting distributions of the elemental and technology supply risk scores. Lognormal distributions were used mostly for physical values from the literature (production volumes, reserves and resources, future technology demand, company concentration). Triangular distributions were used for data with a per-definition minimum and maximum value (e.g., 0 to 100). Normal distributions were given for Worldwide Governance Indicator values. Equal distributions were used if the PPI score of a country was unknown. PPI scores and HDI scores are the results of estimates made by others and are not explicitly modelled with uncertainties (but each production share of a country has a simulated distribution). Table S20 gives a list for all quantitative uncertainty distributions for raw data. The resulting box plot graph is given illustrated in the manuscript as Figure 7. Additionally, the uncertainty analysis box plot for the assessment excluding $\mathrm{Li}, \mathrm{Al}$ and $\mathrm{P}$ is shown in Figure $\mathrm{S} 8$.

Table S24: Assumptions for the distributions required for Monte Carlo (MC) simulation

Data point

Distribution for MC simulation
Standard deviation (Goedkoop A.; Oele, M.; Sipke, D.; de Roest, D. et al., 2007; Graedel et al., 2012; Kaufmann and Kraay, 2015)

\begin{tabular}{lll}
\hline Production volume (country-specific) & Lognormal & GSD $^{2}=1.228^{40}$ \\
\hline Reserves (global) & Lognormal & GSD $^{2}=1.237$ \\
\hline Resources (global) & Lognormal & GSD $^{2}=1.237$ \\
\hline EoL-Recycling Rate & Triangular & Min: 0\%, Max: 100\%, Mean: given \\
\hline By-Product Dependence & Triangular & Min: 0\%, Max: 100\%, Mean: given \\
\hline Future Technology Demand & Lognormal & GSD $=1.228$ \\
\hline Substitutability & Triangular & Min: 0, Max: 100, Mean: given \\
\hline Country Concentration & calculated from country-specific & - \\
\hline Company Concentration & production volumes & \\
\hline WGI-PV (country-specific) & Lognormal & GSD $=1.228$ \\
\hline PPI (country-specific) & Normal & taken from data source \\
& PPI available: no data uncertainty & $-;$ Min: 0, Max: 100 \\
\hline HDI (country-specific) & assumed & \\
\hline Mass, kg/MWp & no data uncertainty assumed & - \\
\hline Commodity price & Lognormal, Triangular & GSD $=1.228$ \\
Cd-Min: 140.1, Cd-Max: $166.6^{\text {Te-Min: } 93.3, \text { Te-Max: } 182.0}$ \\
\hline
\end{tabular}




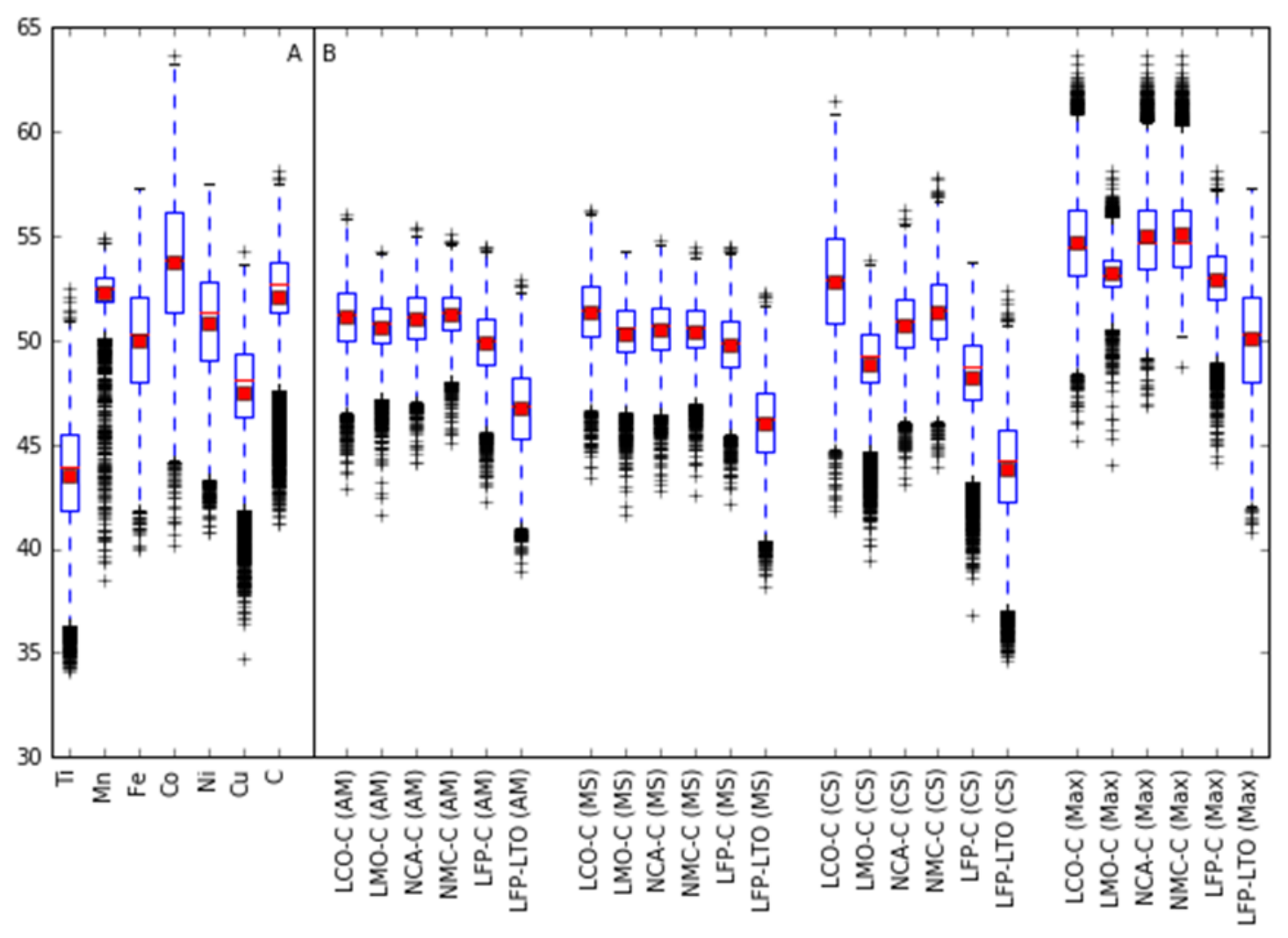

Figure S14: Results of the Monte Carlo simulation with 10000 instances in order to estimate the uncertainty of the supply risk on both the $(A)$ elemental and (B) technology levels, excluding $\mathrm{Li}, \mathrm{Al}$ and $\mathrm{P}$ from the assessment.

Arithmetic mean (AM): each element has same weighting. "Mass-share" (MS) aggregation: elements are weighted according to their mass share in the battery. "Cost-share" (CS) aggregation: elements are weighted according to their raw material cost share. "Maximum" (Max) weighting: the element with highest supply risk determines the supply risk for the technology. 


\section{Comparison of the supply risk scores on the elemental level from different authors}

The following comparison chart can help interpret the results of our study. It should, however, be noted that each study uses a different set of indicators and indicator weightings, depending on the aims of the study concerned, the time horizons and the target groups. Further, the chart only shows a selection of recent studies that give quantitative supply risk scores for several elements, as this was also a requirement of the present study.

A comparison for supply risk scores on the technology level is not possible due to a lack of comparable studies.

Table S25: Comparison chart for supply risk scores on the elemental level in selected previous studies. Study methodologies (indicators, weightings, selected materials) vary considerably.

\begin{tabular}{|c|c|c|c|c|c|c|c|c|}
\hline Element & $\begin{array}{l}\text { This } \\
\text { study }\end{array}$ & $\begin{array}{l}\text { European } \\
\text { Commission } \\
\text { (2017) }\end{array}$ & $\begin{array}{l}\text { European } \\
\text { Commission } \\
(2014)\end{array}$ & $\begin{array}{l}\text { European } \\
\text { Commission } \\
(2010)\end{array}$ & $\begin{array}{l}\text { BGS } \\
(2012)\end{array}$ & $\begin{array}{l}\text { Erdmann } \\
\text { et al. } \\
\text { (2011) }\end{array}$ & $\begin{array}{l}\text { Pfleger } \\
\text { et al. } \\
\text { (2015) }\end{array}$ & $\begin{array}{l}\text { Morley } \\
\text { and } \\
\text { Eatherley } \\
\text { (2008) }\end{array}$ \\
\hline Scale & $0-100$ & $0-10$ & $0-10$ & $0-10$ & $3.3-10$ & $0-1$ & $0-25$ & 4-12 \\
\hline $\mathrm{Li}$ & 54 & 1.0 & 0.65 & 0.73 & 6.7 & 0.39 & 14.3 & 6 \\
\hline Al & 39 & 0.5 & 0.43 & 0.2 & 4.8 & 0.20 & 12.9 & n/av \\
\hline $\mathrm{Ti}$ & 43 & 0.3 & 0.13 & 0.13 & 4.8 & 0.23 & 13.3 & 6 \\
\hline $\mathrm{Mn}$ & 52 & 0.9 & 0.43 & 0.45 & 7.1 & 0.36 & 12.9 & 9 \\
\hline Fe (ore) & 48 & 0.8 & 0.50 & 0.35 & 5.2 & 0.24 & 11.8 & 7 \\
\hline Co & 54 & 1.6 & 1.63 & 1.06 & 7.6 & 0.35 & 15.8 & 9 \\
\hline $\mathrm{Ni}$ & 50 & 0.3 & 0.24 & 0.27 & 6.2 & 0.46 & 13.0 & 9 \\
\hline $\mathrm{Cu}$ & 48 & 0.2 & 0.22 & 0.21 & 4.3 & 0.40 & 13.3 & 8 \\
\hline C (graphite) & 52 & 2.9 & 2.20 & 1.27 & 8.1 & 0.46 & 14.9 & 10 \\
\hline P (phosphate) & 53 & 1.0 & 1.09 & n/av & n/av & 0.36 & 13.0 & $\mathrm{n} / \mathrm{av}$ \\
\hline
\end{tabular}




\section{References}

Angerer, G., Marscheider-Weidemann, F., Lüllmann, A., Erdmann, L., Scharp, M., Handke, V., Marwede, M., 2009. Raw Materials for Emerging Technologies. Frauenhofer IRB Verlag, Stuttgart.

BGS, 2012. Risk List 2012. British Geological Survey.

Buchholz, P., Huy, D., Liedtke, M., Schmidt, M., 2015. DERA-Rohstoffliste 2014.

DERA, 2016. DERA Preismonitor Dezember 2016.

Erdmann, L., Behrendt, S., Feil, M., 2011. Kritische Rohstoffe für Deutschland. KfW Bankengruppe, Berlin.

European Commission, 2017. Study on the review of the list of critical raw materials.

European Commission, 2014. Report on Critical Raw Materials for the EU: Report of the Ad hoc Working Group on defining critical raw materials. European Commission, Brussels, Belgium.

European Commission, 2010. Critical Raw Materials for the EU.

Geoscience Australia, 2013. Australia's Identified Mineral Resources 2013. Canberra.

Goedkoop A.; Oele, M.; Sipke, D.; de Roest, D., M.. D.S., Goedkoop, M., De Schryver, A., Oele, M., Sipke, D., de Roest, D., 2007. Introduction to LCA with SimaPro 7. PRé Consultants.

Graedel, T.E., Allwood, J., Birat, J.-P., Reck, B.K., Sibley, S.F., Sonnemann, G., Buchert, M., Hagelücken, C., 2011. Recycling Rates of Metals - A Status Report, A Report of the Working Group on the Global Metal Flows to the International Resource Panel. UNEP.

Graedel, T.E., Barr, R., Chandler, C., Chase, T., Choi, J., Christoffersen, L., Friedlander, E., Henly, C., Jun, C., Nassar, N.T., Schechner, D., Warren, S., Yang, M., Zhu, C., 2012. Methodology of Metal Criticality Determination. Environ. Sci. Technol. 46, 1063-1070. doi:10.1021/es203534z

Graedel, T.E., Harper, E.M., Nassar, N.T., Reck, B.K., 2015. On the materials basis of modern society. Proc. Natl. Acad. Sci. 112, 6295-6300. doi:10.1073/pnas.1312752110

Jackson, T., Green, K.P., 2016. Fraser Institute Annual Survey of Mining Companies, 2015.

Jackson, T., Green, K.P., 2015. Fraser Institute Annual Survey of Mining Companies, 2014.

Kaufmann, D., Kraay, A., 2015. Worldwide Governance Indicators [WWW Document]. URL http://info.worldbank.org/governance/wgi/index.aspx\#home (accessed 12.1.15).

Lu, Q., Wu, P.F., Shen, W.X., Wang, X.C., Zhang, B., Wang, C., 2016. Life Cycle Assessment of Electric Vehicle Power Battery. Mater. Sci. Forum 847, 403-410. doi:10.4028/www.scientific.net/MSF. 847.403

Marscheider-Weidemann, F., Langkau, S., Hummen, T., Erdmann, L., Tercero Espinoza, L., 2016. Rohstoffe für Zukunftstechnologien 2016, Deutsche Rohstoffagentur (DERA). doi:I D 4 - 020815 $-28 / 07$

Morley, N., Eatherley, D., 2008. Material Security - Ensuring Resource Availability for the UK Economy. C-Tech innovations, Chester.

Nassar, N.T., Graedel, T.E., Harper, E.M., 2015. By-product metals are technologically essential but have problematic supply. Sci. Adv. 1, e1400180-e1400180. doi:10.1126/sciadv.1400180

Natural Resources Canada, 2015. Preliminary estimate of the mineral production of Canada, by province, 2014 [WWW Document]. URL http://sead.nrcan.gc.ca/prod-prod/2014p-eng.aspx (accessed 3.25.15).

Peters, J., Weil, M., 2016. A Critical Assessment of the Resource Depletion Potential of Current and Future Lithium-Ion Batteries. Resources 5, 46. doi:10.3390/resources5040046

Pfleger, P., Lichtblau, K., Bardt, H., Bertenrath, R., 2015. Rohstoffsituation der bayerischen 


\section{Wirtschaft.}

Rankin, W.J., 2011. Minerals, metals and sustainability: meeting future material needs. CSIRO publishing.

Schneider, L., Berger, M., Schüler-Hainsch, E., Knöfel, S., Ruhland, K., Mosig, J., Bach, V., Finkbeiner, M., 2014. The economic resource scarcity potential (ESP) for evaluating resource use based on life cycle assessment. Int. J. Life Cycle Assess. 19, 601-610. doi:10.1007/s11367-013-0666-1 UNDP, 2015. Human Development Report 2015.

UNDP, 2014. Human Development Report 2014.

USGS, 2016. Mineral Commodity Summaries 2016.

USGS, 2015a. Mineral Commodity Summaries 2015. U.S. Geological Survey.

USGS, 2015b. Minerals Yearbook 2014: Volume I - Metals and Minerals.

Vesborg, P.C.K., Jaramillo, T.F., 2012. Addressing the terawatt challenge: scalability in the supply of chemical elements for renewable energy. RSC Adv. 2, 7933. doi:10.1039/c2ra20839c 